\title{
Between liability and asset: a critical review of 25 years of foreignness research in international business
}

DOI:

10.1108/cpoib-07-2020-0102

\section{Document Version}

Accepted author manuscript

Link to publication record in Manchester Research Explorer

\section{Citation for published version (APA):}

An, Y. H., Zagelmeyer, S., \& Rygh, A. (2021). Between liability and asset: a critical review of 25 years of foreignness research in international business. Critical Perspectives on International Business.

https://doi.org/10.1108/cpoib-07-2020-0102

\section{Published in:}

Critical Perspectives on International Business

\section{Citing this paper}

Please note that where the full-text provided on Manchester Research Explorer is the Author Accepted Manuscript or Proof version this may differ from the final Published version. If citing, it is advised that you check and use the publisher's definitive version.

\section{General rights}

Copyright and moral rights for the publications made accessible in the Research Explorer are retained by the authors and/or other copyright owners and it is a condition of accessing publications that users recognise and abide by the legal requirements associated with these rights.

\section{Takedown policy}

If you believe that this document breaches copyright please refer to the University of Manchester's Takedown Procedures [http://man.ac.uk/04Y6Bo] or contact uml.scholarlycommunications@manchester.ac.uk providing relevant details, so we can investigate your claim.

\section{OPEN ACCESS}




\section{Emerald critical perspectives on}

\section{Between Liability and Asset: A Critical Review of 25 Years of Foreignness Research in International Business}

\begin{tabular}{|r|l|}
\hline Journal: & critical perspectives on international business \\
\hline Manuscript ID & cpoib-07-2020-0102.R2 \\
\hline Manuscript Type: & Academic Paper \\
\hline Keywords: & Foreignness, liability of foreignness, asset of foreignness, MNE \\
\hline \multicolumn{2}{|l}{} \\
\end{tabular}

\section{SCHOLARONE \\ Manuscripts}




\title{
Between Liability and Asset: A Critical Review of 25 Years of
}

\section{Foreignness Research in International Business}

\begin{abstract}
Purpose - The dialectics of liabilities of foreignness (LOF) and assets of foreignness (AOF) have led to further explorations of what it means for an organisation to be foreign. This paper reviews, synthesises and contextualises recent research on both the challenges and benefits of foreignness, to develop a balanced and integrated view of this international business concept. Design/methodology/approach - The review maps the key concepts, theories, methods and contexts in the literature and organises key findings in an antecedent-outcomes-strategy framework, explicitly comparing LOF and AOF to explore their interrelationships. Drawing on a sample of 126 journal articles, NVivo was used to code and identify key thematic areas.

Findings - The review confirms a shift in the literature towards acknowledging the notion of AOF. Using different theoretical lenses, it identifies, reviews and discusses antecedents, consequences and strategy implications of LOF and AOF. It argues that foreignness will continue to be a fundamental concept in international business research, and suggests that AOF and LOF deserve an equally central place in an integrated analytical framework of foreignness in international business strategy.
\end{abstract}

Originality/value - The paper is the first systematic attempt to integrate the literature on LOF and AOF. The systematic comparison across drivers, outcomes and strategies allows for a better understanding of the advantages and disadvantages of foreignness and the underlying phenomenon of foreignness. We also explore the paradox perspective on foreignness.

Keywords - Foreignness; Liability of Foreignness; Asset of Foreignness; Multinational Enterprises; Institutional Theory

Paper type - Literature review 


\section{Introduction}

The notion of foreignness plays a key role in international business (IB). The IB literature has traditionally focused on the potential disadvantages for foreign firms, in terms of the additional costs of doing business abroad (Hymer, 1960), being seen as an alien entity in a host country (Hennart, 1982), or being an outsider (Johanson \& Vahlne, 1977). Foreignness has been argued to imply a variety of costs related to lack of knowledge of the local context, lack of access to networks, or even negative discrimination - costs that are not faced by local firms. Zaheer (1995, p.341) conceptualized such costs in terms of the liability of foreignness (LOF), noting that this "has been the fundamental assumption driving theories of the multinational enterprise". Yet, more recently the focus on LOF has been challenged by claims that foreignness can also be an asset (Sethi \& Judge, 2009), for instance due to local stakeholders forming positive expectations of and sympathy for foreigners related to the "opportunities for exploration, learning, and growth" that foreigners can represent (Stahl et al., 2016, p.622). Sethi and Judge (2009) defined the assets of foreignness (AOF) as the unique benefits enjoyed by an MNE subsidiary that are unavailable to host country rivals.

The literature hence suggests that foreignness can have varying implications for firms, being either a liability (LOF) or an asset (AOF) - or possibly both (Edman, 2016). However, the literature still lacks a systematic assessment of how these two aspects of foreignness are related, and under what conditions one or the other will predominate. While previous reviews provided valuable theoretical and empirical overviews of LOF and AOF separately (Luo \& Mezias, 2002; Denk et al., 2012; Mallon and Fainshmidt, 2017), to the best of our knowledge, no review has so far attempted to integrate LOF and AOF literature. Better integration of the insights from these two literatures is crucial for a deeper understanding of the multifaceted impact that foreignness can have in IB, which in turn will also allow MNEs to better manage 
the challenges and opportunities of foreignness. Moreover, a systematic overview and integrated discussion of the effects of foreignness in different contexts may allow a more fundamental understanding of the notion of foreignness itself.

Motivated by the above, we provide an integrated systematic review of the LOF and AOF literatures. Our review explores the dialectical development of the foreignness literature, in which the longstanding assumption of LOF was challenged based on findings that demonstrate that foreignness need not always have a negative effect (Nachum, 2003). This led to the notion of AOF, based on an analogy of the balance sheet, to explore the other side of foreignness. Recently, IB research has endeavoured to synthesise and reconcile LOF and AOF (Edman, 2016b), through exploring new theoretical perspectives and empirical contexts to reexamine foreignness and its effects on MNE operations in foreign markets (NewenhamKahindi \& Stevens, 2017; Oetzel \& Doh, 2009; Stahl et al., 2016). The analysis of potential drivers of the negative or positive impacts of foreignness have also taken centre stage, along with strategies for managing the challenges and opportunities of foreignness.

An integrated literature review of LOF and AOF presents a unique opportunity for understanding the relationship between these phenomena, by examining whether they have similar or different drivers and outcomes, and identifying the conditions under which LOF or AOF predominate. Moreover, a comparison of the theories that have been used to analyse LOF and AOF allows understanding the theoretical development of the literature; the assumptions that have been made and that may be questioned when exploring the other side of foreignness through a dialectical approach (Hoon \& Baluch, 2020); and the extent to which different theories may be needed to understand LOF and AOF. Ultimately, such analysis helps scholars to understand whether LOF and AOF represent difference in kind or degree (Stahl et al., 2016). 
Our integrative review of LOF and AOF contributes to the literature by providing several insights on the conceptual, theoretical and methodological development of these literatures. Firstly, it is demonstrated that not only did AOF arise in a response to LOF, but that some arguments on AOF have closely mirrored key arguments from LOF. The original formulation of the LOF by Zaheer (1995) emphasized spatial distance, unfamiliarity with the local environment, as well as differential treatment and costs imposed by the home country environment. Eden and Miller (2004) later grouped the antecedents of LOF into unfamiliarity, discriminatory and relational hazards. Both similar and different drivers have been posited for AOF (Edman, 2016b; Mallon \& Fainshmidt, 2017) in terms of dissimilarity, relational and discriminatory opportunities.

In terms of theories, we demonstrate how important IB theories such as institutional theory, transaction cost theory and the resource-based view have been applied to both LOF and AOF, indicating how the two phenomena are linked. Although over time institutional theory has played an increasingly prominent role in studies of both LOF and AOF, it is notable that a variety of new theories has been applied recently to study AOF specifically, including the identity-based view. Similarly, the use of different research contexts has also provided further insights into the phenomena (Edman, 2016b; Shi \& Hoskisson, 2012). For instance, studies posit that AOF is more likely to exist in emerging economies where the need for foreign direct investment and knowledge spill-over is higher; foreign firms have more resources than local firms to influence government; the lack of dominant incumbents provides market power; and local firms often also have less legitimacy (Getachew \& Beamish, 2017; Oetzel \& Doh, 2009).

Overall, in response to recent developments in the foreignness literature, the paper contributes by reviewing, synthesizing and contextualizing recent research on LOF and AOF to develop a more balanced view of foreignness. We highlight links between different aspects 
and analytical categories with respect to foreignness research on one hand, and conceptual and theoretical approaches used in IB research on the other (Buckley, Enderwick and Cross, 2018; Buckley and Lessard; 2005; Forsgren, 2017). We conclude that the concept of foreignness still has an important role to play in IB research, a role that may become even more prominent as MNEs are grappling with the recent trends of nationalism, resistance to globalisation and increased scepticism towards foreign firms in many host countries (Meyer, 2017; Witt, 2019a,b). Finally, we explore avenues for linking foreignness and MNE strategy, elaborating especially on how issues related to foreignness can be managed strategically, by considering its paradoxical nature.

Section 2 presents our review methodology, while Section 3 outlines aggregate trends in the literature in terms of concepts, theoretical foundations, methods and empirical contexts used over time and Section 4 provides a more detailed discussion of the antecedents and outcomes of LOF and AOF, and strategies for managing them. Section 5 builds on the previous sections and provides a more extensive discussion of the potential for a synthesis, and suggests directions for further research, before some brief concluding remarks are offered in Section 6.

\section{Review Methodology}

The systematic review followed the process described by Tranfield et al. (2003) and Denk et al. (2012). Using (i) the Web of Science database, (ii) the EBSCO Business Source Premier database, (iii) and Google Scholar, journal articles were identified via full-text searches for "foreignness", "liability of foreignness", "disadvantage of foreignness", "advantage of foreignness" or "asset of foreignness", covering the period 1995 (the year Zaheer's seminal paper was published) to March 2020. We limited our search to peer-reviewed articles in the English language. This yielded a total of 41,713 items, including duplicates. The selection 
process involved several stages, including filtering papers from journals in the fields of international business, management and strategy, evaluating titles and abstracts, and excluding duplicates (Pisani et al., 2017). Additional relevant publications were identified by investigating forward and backward citations from the papers, yielding a preliminary sample of 151 articles (Kolk and Rivera-Santos, 2018).

Insert figure 1 around here

We subsequently tightened the inclusion criteria by accepting only papers that focus on or provide major insights into the phenomenon of foreignness. The authors reviewed all the articles based on a reading of the full text. We considered articles that enhanced understanding of foreignness, LOF and AOF in IB. We excluded articles that address foreignness at the individual level as the main goal was to understand foreignness at company level. At the end of this process, 126 papers were selected for the systematic review (see Figure 1).

NVivo 11 was used to organise and code the full text of the articles. Table 1 shows an overview of journals ranked by the number of contributions. The manual full-text analysis involved two stages. During the first stage, we mapped the literature along the following four dimensions: (1) theoretical foundations and definitions of LOF and AOF; (2) the dyadic perspective, operationalised as country of origin and destination of the foreign direct investment (FDI); (3) the reference points when measuring the degree of LOF or AOF (i.e. whether the investigated firm is compared against host or home market competitors); and (4) the research methodology. Systematic reviews commonly give a descriptive overview of theories and methods. Moreover, we added the dyadic and relative contextual perspectives as in Denk et al. (2012) due to the insights that these perspectives provide on foreignness. 
In the second stage, to gain a better understanding of foreignness aspects relevant to strategic decision-making, we covered the following additional themes: definitions, antecedents and consequences of LOF and AOF, and strategies for managing them, in particular corporate responses to perceptions and expectations in the external environment, or proactive management of aspects related to foreignness.

Insert table 1 around here

The following sections present and discuss the findings from our literature review. We first provide a general overview of the literature in terms of the study of the LOF and AOF concepts, and the theories, methods, research contexts and reference points used. We then provide an indepth discussion, following a structure of antecedents, outcomes and strategies, similar to other systematic reviews (e.g. Paul \& Benito, 2018). Throughout, our discussion highlights the dialectical features of the foreignness literature by contrasting the LOF and AOF perspectives.

\section{LOF and AOF: Concepts, theories, methods and contexts}

This section provides a broad overview of the development of the foreignness literature in terms of the key concepts, theories and methods used, and contexts investigated.

\subsection{LOF and AOF concepts}

\section{Liabilities of Foreignness}

Defining LOF as "the costs of doing business abroad that result in a competitive disadvantage for an MNE subunit" (Zaheer, 1995, p.342), early studies elaborated upon the cost of doing 
business abroad (Hymer, 1960), with foreign companies assumed to face extra costs because of a lack of information, discrimination, home country institutional constraints and exchange rates. Based on institutional and social network theories, LOF studies conceptualised such costs as structural/relational costs and institutional costs incurred in comparison to local firms (Sethi \& Judge, 2009; Zaheer, 2002). Studies subsequently delineated and extended the concept in various ways, such as by considering LOF as a location-specific construct, representing a cost that affects all foreign companies within a particular host country context (Edman, 2016b; Sethi \& Judge, 2009), and distinguishing it from related concepts such as liabilities of multinationality, i.e., the challenges of operating within the multinational context (Sethi \& Judge, 2009); or liabilities of origin, i.e., costs incurred due to the country-specific origin of the firm (Moeller et al., 2013; Ramachandran \& Pant, 2010).

Studies have further subcategorised LOF as unfamiliarity, discriminatory and relational hazards (Eden \& Miller, 2004). Unfamiliarity hazards reflect a lack of knowledge or experience of the host country, while discriminatory hazards arise from differential treatment by the home or host governments, consumers or the general public (Eden \& Miller, 2004; Sethi \& Judge, 2009). Relational hazards derive from internal organisation costs such as the difficulties of managing employees at a distance and from different cultures (Calhoun, 2002) and interorganisational costs such as those incurred when building trust and relationships with domestic stakeholders (Kostova \& Zaheer, 1999; Zaheer, 2002). Denk et al. (2012) later added a fourth category that included drivers of LOF such as distance (i.e., cultural, institutional, spatial, linguistic), host country, industry and firm characteristics. Another conceptualisation linked LOF to Dunning's eclectic paradigm by identifying ownership-specific LOF, location-specific LOF and internalisation LOF (Denk et al., 2012; Zhou \& Guillen, 2016). Overall, the literature 
has identified a variety of possible types of LOF, but until recently paid less attention to the possibility of AOF.

\section{Assets of Foreignness}

In the early 2000 s, scholars started to recognize that foreignness could also be an advantage (Brannen, 2004; Nachum, 2003; Newburry et al., 2006). The term "asset of foreignness", directly framed against the notion of "liabilities", seems to have first appeared in Sethi and Guisinger (2002), referring to how MNEs could convert LOF into AOF through better "reading" of the international business environment. Research also suggests that certain types of AOF reduce the costs of LOF (Mallon \& Fainshmidt, 2017). These arguments suggested that LOF can be managed and even become an asset. Sethi \& Judge later defined the assets of foreignness as "unique benefits enjoyed by an MNE subsidiary that are unavailable to hostcountry rival firms" (2009, p.409). Subsequent studies generally use the terms "advantages" and "assets" of foreignness interchangeably to include tangible and intangible benefits of foreignness (Edman, 2016b; Mallon \& Fainshmidt, 2017), although Shi \& Hoskisson (2012) positioned intangible advantages of foreignness such as the scope for "creative institutional deviance" against more tangible assets of foreignness such as subsidies and tax breaks.

The literature also distinguished AOF from other types of advantages such as ownership advantages that were traditionally assumed to be necessary to overcome LOF (Hymer, 1960). Mallon and Fainshmidt (2017) differentiate between AOF and ownership advantage, claiming that $\mathrm{AOF}$ is the benefit or advantage incurred in the host country by a foreign firm due to its "foreignness", an advantage that domestic firms would not be able to easily access or replicate, whereas ownership advantage refers to capabilities or resources "unique" to the firm occurring across different contexts. 
AOF is still a recent concept compared to LOF, often treated as an exception with LOF as the standard (Stahl et al., 2016). Interestingly, assets of foreignness have often been conceptualised in similar ways to liabilities. Mirroring the relational, discriminatory and uncertainty hazards (Eden \& Miller, 2004), some literature distinguishes three categories of AOF: dissimilarity, relational and discriminatory opportunities (Mallon \& Fainschmidt, 2017). This again illustrates notable dialectic features of the literature, whereby specific assets are posited in response to specific liabilities. For instance, the traditional assumption in the literature since Hymer (1960) has been that foreign firms may face negative discrimination from host governments and other actors. However, positive discrimination and initial legitimacy for foreign companies may also exist because of a lack of local firm legitimacy, e.g. due to local firms being (over)protected by their government, the government's need for foreign direct investment, and/or a foreign firms' superior age or other firm-specific advantages (Edman, 2016b; Kostova et al., 2008; Sethi \& Judge, 2009; Taussig, 2017). In addition, host country xenophilia and a long-standing sense of the inferiority of domestic companies may also play a role (Kostova \& Zaheer, 1999).

Similarly, the literature has identified AOF in terms of relational opportunities. Kostova et al. (2008) argued that MNEs do not necessarily need to comply with local pressures because of their unique positioning in the local environment. MNEs are often exposed to many institutional systems and relationships (Kostova and Zaheer, 1999), so in a way are buffered, protected, less dependent and in some cases exempt from institutional pressures (Regnér and Edman, 2014). The unique position of MNEs also implies fewer local ties in the host country (Denk et al., 2012). This can be a liability (Johanson and Vahlne, 2009), but the lack of ties in some cases allows MNEs to innovate, rather than adopting local practices (Edman, 2016a). 
Furthermore, MNE subsidiaries have the advantage of buffering unethical pressures such as corruption due to the lack of ties and their unique position (Spencer and Gomez, 2011).

Furthermore, assets of foreignness have been posited in relation to dissimilarities between host and home country institutions. These can provide foreign firms with increased reflexivity i.e. the ability to consider actions, behaviours and solutions beyond the constraints imposed by host country institutions (Mallon \& Fainshmidt, 2017; Siegel et al., 2019; Un, 2016). In addition, the heterogeneous culture of the host country, foreign firms' lack of ties and distinct expectations held by local stakeholders can enable foreign firms to buffer local pressures and undertake distinct actions and norm-breaking behaviours (Edman, 2016a; Kostova et al., 2008; Regnér \& Edman, 2014; Rodgers et al., 2019; Yildiz \& Fey, 2012).

\subsection{Theories, methodology and empirical context}

\section{Theories}

The five dominant theoretical lenses applied in the foreignness literature are institutional theory, internationalisation theory, the resource-based view, the knowledge-based view and social network theory. Many early papers analysed LOF or AOF without an explicit theoretical lens. However, we see a rise in number of papers applying institutional theory, internationalisation theory, the resource-based view and social network theory throughout the sample period. Scholars use these approaches to develop the concept of LOF and AOF and to explain the role of foreignness in the interplay between institutions, MNE subsidiaries and strategic responses (Regnér \& Edman, 2014; Stahl et al., 2016). Institutional theory explains LOF by focusing on the unfamiliarity stemming from institutional differences between home and host country (Calhoun, 2002; Mezias, 2002; Zaheer, 1995). To overcome these costs, scholars using the 
legitimacy and isomorphism aspects of institutional theory literature argue that MNEs need to imitate local firms (Salomon and $\mathrm{Wu}, 2012$; Wu and Salomon 2016). However, scholars also increasingly use institutional theory, including the institutional logics perspective, to provide new views on foreignness, LOF and AOF (Edman, 2016a; Regnér \& Edman, 2014; Taussig, 2017). For instance, studies posit that foreign MNEs are subject to different expectations and logic, and thus foreign firms do not need to imitate local firms (Kostova et al., 2008). Foreignness is an asset that can foster innovation and buffer local pressures (Edman, 2016a; Mallon \& Fainshmidt, 2017; Newenham-Kahindi \& Stevens, 2017; Yildiz \& Fey, 2012).

Studies applying the theories of international expansion are divided into two categories: (1) the internalization perspective on foreign expansion, focusing on aspects such as transaction cost and (2) the Uppsala model of internationalization, focusing on learning, and access to information and networks. Studies applying the international expansion theories focus on the effect of LOF on firm internationalization. Internationalization theory focuses on uncertainty, relational and discriminatory hazards of LOFs and the strategies to overcome them (Asmussen and Goerzen, 2013; Gaur and Lu, 2016; Johanson and Vahlne, 2009). This stream of research follows the argument made by Hymer (1960) that foreign firms lack information, network and face discrimination in the host country. Thus, to overcome the costs, foreign firms need to choose a suitable entry mode to learn and acquire resources, knowledge and information in the environment (Acheampong and Dana, 2017; Asmussen and Goerzen, 2013; Elango, 2009; Kudina, 2012). Another stream of research argues that LOFs affect MNE expansion strategy where firms tend to face lower LOFs within same regional area (Asmussen, 2009) or global cities (Goerzen et al., 2014; Nachum, 2003). Recently, deviating from the conventional wisdom that foreignness is a liability due to weak relational ties (Johanson and Vahlne, 2009), studies argue that foreignness is an asset as it provides buffer from institutional pressures (Edman, 
2016a, Kostova et al., 2008), government support or cooperation (Parente et al., 2018; Sethi and Judge, 2009) and bargaining power (Eden and Molot, 2002; Oetzel and Doh, 2009).

Research applying social network theory, the knowledge-based view and the resourcebased view to foreignness focused on LOF. These studies argue that foreign MNEs lack local networks, knowledge and resources in the host environment (Denk et al., 2012). To overcome LOF, research applying the three theories argued that firms must build local networks and ties to access resources (Bucheli \& Salvaj, 2018; Johanson \& Vahlne, 2009; Sojli \& Tham, 2017) and exploit unique tangible and intangible resources and capabilities unavailable to domestic rivals by integrating local and global knowledge (Cuervo-Cazurra et al., 2007; Li et al., 2016; Regnér \& Zander, 2014; Un, 2011, 2016). Studies also increasingly focus on the types of networks and how foreignness as a firm-specific resource provides an advantage for foreign MNEs. Research posits that high-status local exchange partners provide foreign firms with greater opportunities and benefits (Yu \& Sharma, 2016) as well as innovation, by exploiting niche networks (Edman, 2016a). Also, foreignness enables the development of resources and capabilities, which provides advantage in hiring socially-excluded groups (Siegel et al., 2019), product innovation (Un, 2011, 2016) and profitability (Taussig, 2017).

Recently, there has been a notable increase in theoretical pluralism in the study of LOF and AOF. Since Denk et al. (2012), studies have investigated the foreignness phenomenon using a wide variety of new theoretical perspectives, such as the identity-based view (Edman, 2016b), attribution theory (Crilly et al., 2016), cognitive categorisation theory (Obadia, 2013), organizational learning theory (Petersen and Pedersen, 2002), density dependence (Miller and Eden, 2006), the spill-over perspective (Oetzel and Doh, 2009) and the social semiotic perspective (Brannen, 2004). For instance, based on the identity perspective, Edman (2016b) suggests that MNE subsidiaries can, to some extent, manage their foreignness in a local context, 
through accentuating or attenuating internal and external features such as cognitive attributes (e.g. mindsets and frames), structural attributes (language used, managerial culture, incentives and other organizational practices), their external network position, and their image as an “alien” or outsider.

It is also notable that theorisation on AOF has sometimes involved the use of different theories than for LOF. Brannen (2004) uses a social semiotic perspective to argue that foreignness was an asset for Disney's operations in Japan because of the fit between the foreign signs and image of Disney's products and practices and the host country's foreign perception and expectations. Newburry et al. (2006) apply the organisation attractiveness perspective to argue that foreignness is an asset in terms of attracting highly qualified individuals. Their study uses foreign headquarters and the extent of foreign operations as foreignness dimensions, and finds that foreignness increases organisation attractiveness. Shi and Hoskisson (2012) combined institutional theory with a social comparison perspective, arguing that foreign firms may in some cases be seen as less relevant comparisons to local firms due to their different characteristics, and therefore also less subject to pressures for isomorphism.

These new theoretical perspectives also help scholars to explain the phenomenon in under-researched contexts, such as African countries, where the assumptions of conventional LOF theories may be less applicable (Newenham-Kahindi \& Stevens, 2017). This will be elaborated further below in our discussion of research contexts.

\section{Research Methods}

Various research methods have been employed in the foreignness literature. Of the 126 papers reviewed, 73 were quantitative, 17 qualitative and 34 purely conceptual. Only two papers (Balabanis \& Diamantopoulos, 2016; Crilly et al., 2016) used mixed methods. There is a clear 
dominance of quantitative studies, frequently using measures of institutional, cultural, economic and political distance between diverse samples of host and home countries to analyse the effect of foreignness (Salomon \& Wu, 2012; Wu \& Salomon, 2017; Zhou \& Guillen, 2016).

However, the findings show increased use of qualitative methodology, which seems to be related to studies shifting focus from investigating LOF and strategies for mitigating them, to investigating AOF and a deeper understanding of foreignness itself. The increased number of studies investigating foreignness in the context of traditional emerging markets also partly explains the increased use of qualitative methodology. Emerging and developing markets, including African countries, often are not covered by standard secondary databases, requiring primary data collection, notably via interviews (Ghauri, 2004). Furthermore, qualitative methodology has enabled studies to explore the complex social interactions involving foreignness, including those between MNE subsidiaries and host country institutions. Consequently, the increase of qualitative methodology led to more emphasis on the role of foreignness in enabling strategic agency, and on the positive side of foreignness.

Insert figure 2 around here

\section{Empirical Context}

Table 3 provides information on the empirical setting of foreignness studies since 1995 . The first empirical studies focused on the effect of foreignness in foreign direct investment (FDI) flows from one developed country to another, or from developed and developing countries to other developed or developing countries (a sample structure we term "various markets"). However, throughout the sample period, scholars utilised more diverse contexts, with a 
noticeable shift towards emerging markets. Also, studies have increasingly investigated FDI from emerging markets to various markets.

Establishing the reference point for foreignness helps us understand the characteristics of foreignness and its effects. Not all studies compare foreign firms to domestic firms: some compare foreign firms with one another, or both foreign and domestic firms (Table 3). Such comparisons are important to understand the relationship between country-level and firm-level drivers of foreignness. The first studies focused on comparing foreign and local companies, inferring the existence of LOF from performance differentials between foreign and local companies (Zaheer, 1995; Zaheer \& Mosakowski, 1997). Later studies compared foreign companies with local companies and foreign companies with one another, helping to understand the different strategies used by foreign companies and their different LOF or AOF (Brannen, 2004; Goodall \& Roberts, 2003; Luo et al., 2002). Studies utilising the foreign to local perspective endeavour to explore the antecedents and consequences of LOF (Hennart et al., 2002; Li et al., 2008; Mezias, 2002a; Newburry et al., 2006) and strategies to mitigate LOF.

Insert figure 3 around here

Throughout the sample period, while scholars still attempted to determine the existence of LOF in different empirical contexts (Kolk et al., 2014; Salomon \& Wu, 2012; Yu \& Kim, 2013) and explore mitigation strategies (Mithani, 2017; Newenham-Kahindi \& Stevens, 2017; Regnér \& Edman, 2014; Wu \& Salomon, 2016), three new foci emerged. These foci are: the particular contexts within which AOF exists (Edman, 2016a; Mallon \& Fainshmidt, 2017; Shi \& Hoskisson, 2012); the dynamics of foreignness (Crilly et al., 2016; Salomon \& Wu, 2012; 
Taussig, 2017); and the simultaneous management of both AOF and LOF (Edman, 2016b; Regnér \& Edman, 2014; Siegel et al., 2019). We turn to these aspects in the next sections.

\section{Antecedents, impact and response strategies}

We next explore the various drivers and consequences of LOF and AOF considered in the literature, before turning towards management strategies. The findings are presented in relation to the dominant theoretical lenses to highlight the expanding boundaries of LOF and AOF.

\subsection{Antecedents of liabilities and assets of foreignness Antecedents of LOF}

The antecedents of LOF fall into two categories: country-level and firm-level (Denk et al., 2012; Guar et al., 2011). Zaheer (1995) initially applied institutional theory to posit four antecedents of LOF: spatial distance, unfamiliarity, differential treatment and costs imposed by the host or home country environment. Scholars applied the five dominant theoretical lenses identified above to posit diverse antecedents of LOF. Specifically, institutional theory focused on antecedents of LOF at country level, especially institutional, cultural, linguistic and spatial distance (Eden \& Miller, 2004; Elango, 2009; Xu \& Shenkar, 2002). Scholars using internationalisation theory continued to accept the antecedents identified by Hymer (1960) and Zaheer (1995), in terms of lack of knowledge and experience and discrimination (Asmussen, 2009; Johanson \& Vahlne, 2009; Kronborg \& Thomsen, 2009). Social network theorists added lack of relationships and embeddedness as antecedents (Johanson \& Vahlne, 2009; Li et al., 2008), further extending the relational costs proposed by Zaheer (2002). Studies applying the resource-based view claimed the antecedents of LOF to be the bargaining power of the host country government (Eden \& Molot, 2002), dissimilarity between the host and home country environments, and discrimination by host country stakeholders (Cuervo-Cazurra et al., 2007). 
While early LOF studies focused on the country-level antecedents of LOF, later studies applying institutional theory and social network theory investigated the firm-level antecedents by placing as the central antecedents of LOF the network position of the firm and the distinct cognitive constructs or underlying cognitive assumptions, frames and mental models that guide members in making sense of who the organisation is, its goals, and legitimate ways for achieving these goals in the local environment (Edman, 2016a; Johanson \& Vahlne, 2009; Newenham-Kahindi \& Stevens, 2017; Regnér \& Edman, 2014). For example, NewenhamKahindi and Stevens (2017) find that foreign MNEs experience conflict with local stakeholders in Sub-Saharan Africa because the MNEs emphasise transactional relationships and financial success, while local stakeholders value relationships, trust and holistic well-being. Studies also emphasised foreign firms' lack of knowledge as an antecedent of LOF rather than the dissimilarity between the host-home country institutions, problematizing the predominant use of national cultural distance as a measure of LOF (Mezias et al., 2002).

Scholars also include lack of local legitimacy, the erosion of firm-specific advantage and a low degree of embeddedness as antecedents of LOF (Bell et al., 2011; Guar et al., 2011). Zhou and Guillen (2016) apply the OLI paradigm to reconcile country-level and firm-level antecedents by identifying product adaptation cost (ownership-specific LOF), discrimination cost (location-specific LOF) and governance and appropriation costs (internalization LOF). However, because country-level antecedents have strongly influenced the theorization and measurement of LOF, studies continue to investigate both country-level and firm-level antecedents (Campbell et al., 2012; Edman, 2016a; Newenham-Kahindi \& Stevens, 2017; Rodgers et al., 2019; Wu \& Salomon, 2017; Zhou \& Guillen, 2016).

Antecedents of $A O F$ 
The antecedents of AOF, like the antecedents of LOF, can be categorised into country-level and firm-level. Proposed country-level antecedents include home-host country dissimilarity and host country environment (Mallon \& Fainshmidt, 2017; Nachum, 2010; Oetzel \& Doh, 2009; Sethi \& Judge, 2009), while firm-level antecedents include differences in cognitive assumptions, structures and practices, network position and distinct expectations and perceptions of foreign firms (Brannen, 2004; Edman, 2016a, 2016b; Newburry et al., 2006; Rodgers et al., 2019; Siegel et al., 2019; Taussig, 2017; Un, 2016).

The view of foreignness as an asset developed especially in the early 2000s, with scholars applying social semiotics (Brannen, 2004), organisation attractiveness (Newburry et al., 2006) or spill-over perspectives (Oetzel \& Doh, 2009), or analysing LOF and AOF without using the traditional theoretical lenses (Sethi \& Judge, 2009). These studies focus on countrylevel antecedents such as the host country's xenophilia and the need for FDI (Oetzel \& Doh, 2009; Sethi \& Judge, 2009), lack of local firm legitimacy (Oetzel \& Doh, 2009) and the fit between foreign firm product, practices and image and the host country's expectations of foreignness (Brannen, 2004). However, Newburry et al. (2006) also find that traits associated with internationalisation, such as reputation, innovation and brand equity, may imply a greater likelihood of attracting employees from specific demographic groups. Later, Siegel et al. (2019) complemented this study, finding that foreign firms attract more female employees because of distinct human resource management (HRM) practices.

Recently, scholars applied both mainstream and new theoretical lenses to identify further country-level and firm-level antecedents of AOF. Studies apply the institutional theory/logics perspective to argue that host country dissimilarity is an antecedent of AOF, as it promotes reflexivity in terms of the ability of foreign companies to look beyond the constraints of local institutions, in turn providing them with advantages in innovation (Mallon \& 
Fainshmidt, 2017). Institutional theorists also find that firm-level antecedents of AOF, such as distinctive assumptions, network position and expectations that separate foreign firms from local firms, can drive innovation and strategic pluralism (Edman, 2016a; Regnér \& Edman, 2014; Un, 2011). Studies using the knowledge-based view, social network theory and the identity-based view also focused on firm-level antecedents, arguing that diversity within foreign companies allows reflexivity and gives foreign firms an advantage over local firms (Edman, 2016b; Rodgers et al., 2019; Un, 2016).

\section{Summary of antecedents of LOF and AOF}

Table 5 provides an overview and comparison of the antecedents of LOF and AOF. It highlights how many antecedents, such as home-host country dissimilarity and weaker embeddedness in local networks, can have both negative and positive effects. For instance, an outsider position in terms of local networks can have costs in terms of lower trust or access to information, but it may also have benefits in terms of being buffered against unfavourable isomorphic pressures.

Insert table 2 around here

\subsection{Impact of Liabilities and Assets of Foreignness}

\section{Consequences of LOF}

Denk et al. (2012) distinguish three categories of consequences of LOF. The first category involves business impacts, such as financial performance (e.g. return on assets or return on sales), firm growth, survival and exit rates. Studies applying institutional theory and internationalisation theory have found that LOF reduces the performance of foreign companies 
compared to local firms. Some studies investigate the difference between the average performance of local firms and the performance of foreign subsidiaries (Nachum, 2003; Zaheer, 1995), while others compare the exit or survival rate of foreign and local companies to explore the effect of LOF. Zaheer and Mosakowski (1997) find that foreign companies have a higher exit rate, but that this difference decreases over time. Other studies find that foreignness is negatively related to firm growth, profitability, profit per employee, return on assets and return on sales (Denk et al., 2012; Miller \& Eden, 2006).

The second category mainly involves intra-organizational processes. Most of the studies using institutional theory find consequences of LOF in influencing internal business processes by which firms internationalise (Denk et al., 2012). The intra-organizational processes illustrate how LOF affects internal business processes, by weakening firm-specific advantages (Boehe, 2011), and increasing the costs of internal governance and knowledge transfer (Calhoun, 2002; Mezias \& Mezias, 2010; Schmidt \& Sofka, 2009).

The third category includes a variety of outcomes from foreignness, such as the probability of lawsuits (Mezias, 2002b), reputational and relationship damage (Kostova \& Zaheer, 1999), degree of embeddedness (Nachum, 2010), crime (Acheampong \& Dana, 2017), organizational attractiveness, and discrimination (Crilly et al., 2016; Edman, 2016b; Maruyama \& Wu, 2015; Newburry et al., 2006). Mezias (2002b) finds that foreign firms face a higher number of lawsuits than local firms in the US. Acheampong and Dana (2017) show that foreign firms suffer more damage from crime compared to local firms, despite higher security expenditure. Crilly et al. (2016) find that foreignness negatively influences a company's CSR performance. Furthermore, Newenham-Kahindi and Stevens (2017) claim that inter-relational conflict is likely to occur between local actors and MNE subsidiaries because of differences in decision-making, economic activity, and sources of legitimacy and identity. 


\section{Consequences of $A O F$}

Similar to the consequences of LOF, the business impact of AOF includes higher returns on assets (Nachum, 2010) and survival rate (Kronborg \& Thomsen, 2009). However, scholars using the knowledge-based view, institutional theory and the identity-based view find that foreignness is positively associated with innovation (Edman, 2016a, 2016b; Regnér \& Edman, 2014; Regnér \& Zander, 2014; Un, 2011, 2016), deal performance, and/or the compounded annual rate of return on investment for each deal made by private equity firms (Taussig, 2017). Although many studies claim that LOF weakens firm-specific advantages, knowledge spillovers and trust, Un $(2011,2016)$ argues that foreignness drives innovation because of multiculturalism and diversity.

The consequences of AOF for the second category of internal organizational outcomes include ownership advantage attributed to foreignness (Mallon \& Fainshmidt, 2017), advantages in disengaging or disconnecting from host country institutional pressures (Shi \& Hoskisson, 2012), ease in complying with regulations (Rodgers et al., 2019), and exploiting market voids and enjoying first-mover advantage over local firms (Edman, 2016b). Interestingly, Regnér and Edman (2014) find that foreignness is an advantage in responding to host country institutional processes, enabling foreign companies to circumvent or adapt to local pressures flexibly. Studies have predominantly used institutional theory, the identity-based view and the resource-based view to identify the consequences of AOF. However, compared to the consequences on business impact and inter-organisational relationships, the second category of intra-organisational processes has been relatively under-studied.

The third category includes the consequences of AOF in inter-organisational relations. Institutional and identity-based theorists find negative perceptions of local firms (Oetzel \& Doh, 
2009) and/or positive perceptions of foreign firms (Edman, 2016b), disengagement and buffering against local pressures (Shi \& Hoskisson, 2012), organisational attractiveness and access to human capital (Newburry et al., 2006; Siegel et al., 2019) to be consequences of AOF. On the other hand, internationalisation theorists view bargaining power with the host country government, internalisation advantages, subsidies and incentives as consequences of AOF (Mallon \& Fainshmidt, 2017).

\section{Summary of consequences of LOF and AOF}

Table 5 summarizes the consequences of LOF and AOF. While foreignness has been found to both negative and positive effects on outcomes such as ROA or survival, depending on the study, an outcome particularly associated with AOF seems to be increased innovation. The findings show that studies have predominantly focused on AOF in innovation, compared to other consequences on business impact. Overall, studies of AOF have focused on intangible consequences, while LOF studies focus on both tangible and intangible consequences. This seems to be in line with the suggestion by Shi and Hoskisson (2012) that advantages of foreignness may take intangible forms. One might speculate that this explains why AOF have received less attention in the literature until recently.

Insert table 3 around here

\subsection{Strategies to manage LOF and AOF}

Beyond the shift of the academic debate on foreignness towards a more balanced view acknowledging the potential benefits and advantages, we turn to the practical implications for managing liabilities and assets of foreignness strategically. 


\section{Managing LOF}

Traditionally, the literature has assumed that the main strategies for mitigating LOF are to deploy firm-specific ownership advantages, and/or to pursue institutional isomorphism (e.g. Shi \& Hoskisson, 2012; Edmans, 2016b). While studies using the dominant institutional-based view of foreignness argue that isomorphism reduces LOF (Bell et al., 2011; Salomon \& Wu, 2012; Wu \& Salomon, 2016), recent studies emphasise MNE subsidiary agency, where foreign companies can potentially circumvent local expectations (Kostova et al., 2008; Regnér \& Edman, 2014), and engage in political activities and lobbying to mitigate LOF (Bucheli \& Salvaj, 2018; Kline \& Brown, 2019). In addition to isomorphism-related strategies, studies using internationalisation theories, social network theory and the resource-based view argue that foreign companies mitigate LOF by leveraging firm-specific assets and building relationships in the host country (Elango, 2009; Garg \& Delios, 2007; Luo et al., 2002; Petersen \& Pedersen, 2002; Zaheer, 1995).

Recent institutional theorists are shifting away from a notion of "isomorphic fit" to one of "strategic fit". Newenham-Kahindi and Stevens (2017) find that subsidiaries may co-create logics with locals to mitigate LOF, showing how the logics or cognitive mindset of foreign subsidiary managers interact with local constituent logics through local employees who understand both local and foreign mindsets. Edman (2016b) argues that foreign subsidiaries can downplay foreign organisation attributes by incorporating local norms and assumptions into the organisation, using local language and practices and embedding themselves into suitable networks. Parente et al. (2018) illustrates how a Chinese company in Central Africa leveraged its firm-specific resources and endeavoured to becomes an insider in the local environment, assuming the role of a business ecosystem leader. 
The recent literature has thus provided a more nuanced perspective on how foreign firms can mitigate LOF through institutional agency, political activities and co-evolution with local institutions. However, MNEs also need to consider the management of potential AOF, to which we turn next.

\section{Managing $A O F$}

Contrary to traditional assumptions of isomorphism and the need to become embedded in local networks, recent research suggests that foreign subsidiaries leverage AOF by deliberately positioning themselves in the external network, maintaining a minority identity and exploiting the disparities between the home and host country institutions. Outsidership promotes the subsidiary's ability to find opportunities in the market while buffering against isomorphic pressures to conform to the host market (Edman, 2016a, 2016b), increasing the scope for creative institutional deviance (Shi \& Hoskisson, 2012). Mallon and Fainshmidt (2017) claim that foreign subsidiaries have advantages in terms of innovation because of institutional asymmetries in terms of the difference between home and host country institutions. However, subsidiaries with the resources to leverage opportunities can create firm-specific resources by recombining existing firm resources with institutional resources to create further advantages.

Similarly, Edman (2016b) suggests that subsidiaries can manage their foreignness through emphasizing or downplaying foreign attributes such as internal organization, mindsets, external network position and their local image. Edman (2016b) provides several proposals of how various attributes can be managed to leverage AOF. For instance, strengthening the foreignness of a company's image can increase xenophilia.

Summary of Management of LOF and AOF 
Table 6 summarizes the findings from the literature on the strategic management of LOF and AOF, listed by theoretical lens. A notable difference is found in the strategy of isomorphism or seeking embeddedness to avoid LOF, while on the other hand exploiting the outsider network position in the case of AOF. However, it is also noteworthy that compared to studies of LOF, AOF studies have so far focused relatively less on strategic responses or specific mechanisms.

Insert Table 4 around here

\section{The road forward for foreignness research: Towards a synthesis}

In the past 25 years, research on foreignness as a core concept in the academic field of international business has evolved from an almost exclusive focus on liabilities to a more balanced view of the phenomenon and its consequences for businesses operating across borders, emphasising the relevance of both liabilities and assets of foreignness. Despite this, in the absence of an integrated analytical framework and a more fundamental understanding of foreignness, mainstream IB and management literature all too frequently reduces the phenomenon to liabilities only. Turning from the discussion of conceptual issues related to foreignness to MNE strategy behaviour, empirical research reviewed above provides clear evidence that MNEs seek both to minimise the negative impact of liabilities of being foreign and to maximise the returns on assets of foreignness.

Operating a business organization in a complex and dynamic institutional environment poses specific challenges for management (Greenwood et al., 2011), and in particular for MNEs (Eden \& Nielsen, 2020; Kostova \& Roth, 2002; Kostova \& Zaheer, 1999). With respect 
to academic research and management practice, the phenomenon of foreignness has a complex and dynamic context. Several questions emerge. Are liabilities and assets best seen as opposite poles along a continuum, or are liabilities and assets entirely independent phenomena? If the latter, are there interaction effects between LOF and AOF? With respect to managing foreignness strategically, what are the respective roles of headquarter and subsidiary strategies? Do different subsidiaries of the same MNE in the same or different countries face different consequences of foreignness, in terms of type, magnitude, and the effective response? Will the consequences of being perceived as foreign be stable, or change over time? While this paper will not be able to fully answer all these questions, it attempts to identify, explore and discuss important open questions and desiderata with respect to the conceptualization of foreignness, empirical research and implications for MNE behaviour and international business strategy.

Both the complexity and dynamics of the international business environment may lead to researchers and managers facing paradoxes, which denote "contradictory yet interrelated elements - elements that seem logical in isolation but absurd and irrational when appearing simultaneously" (Lewis, 2000, p. 760). Over the past three decades of work, paradox research has moved from conceptualization and the role of paradoxes for theory construction (Poole and Van de Veen, 1989) to the development of a paradox framework (Lewis, 2000) to paradox theory (Schad, Lewis, and Smith, 2018; Smith and Lewis, 2011). Later sections will link the discussion of foreignness to paradox research, which offers promising insights with respect to analysing and discussing paradoxes in the context of change and dynamics (Beech, Burns, de Caestecker, MacIntosh, and MacLean, 2016; Lüscher and Lewis, 2008) and institutional complexity (Pant and Ramachandran, 2017; Smith and Tracey, 2016) and its impact on organizational life, management and strategy development. 


\subsection{Conceptualization of and theorizing on foreignness}

Despite the theoretical and empirical advances reported in previous sections concerning our understanding of the phenomenon of foreignness, its antecedents and consequences, there remain challenges with respect to conceptualisation and theorisation, and potential links between these issues. Previous research has tended to focus more on LOF as a reflection of foreignness, rather than defining and exploring what foreignness is and the attributes that build foreignness as a trait of MNE subsidiaries (Stahl et al., 2016). At the most basic level, the term 'foreignness' refers to the identity of MNE subsidiaries. Foreignness has been defined by some studies as the "dissimilarity - or the lack of fit - between the home and host country environments of multinational enterprises" (Brannen, 2004: 596). Such home-host country dissimilarities, specifically in the form of institutional distance, renders foreign subsidiaries "aliens" (Hennart, 1982) and "outsiders" in the host country (Johanson \& Vahlne, 2009).

The literature indicates two perspectives on foreignness: "difference in kind" and "difference in degree" (Edman, 2016b). The difference in kind perspective, mainly associated with the identity-based view and/or the institutional logics perspective, explicitly conceptualises being foreign as an organisation identity that separates MNE subsidiaries from local firms (Edman, 2016a, 2016b). Foreignness is implicitly treated as a separate category or a quality of a collective group because MNE subsidiaries are only perceived as outsiders or foreign when they engage in business abroad (Zaheer, 2002). An MNE is unlikely to be perceived as foreign in the country of its headquarters, whereas foreignness implies different expectations and perceptions from those of local companies (Edman, 2016a; Regnér \& Edman, 2014; Un, 2011). Foreign companies bring with them distinct mindsets, structures and routines (Rosenzweig \& Singh, 1991), as well as their own perceptions and stereotypes of other foreign cultures that affect their information processing, trust-building and strategies in the host 
country (Newenham-Kahindi \& Stevens, 2017; Obadia, 2012). Thus, foreignness is a defining trait of MNE subsidiaries that guides their behaviour (Crilly et al., 2016).

Yet, most studies focus on difference in degree, by linking LOF and AOF with distance measures (Denk et al., 2012). This is frequently related to the institutions-based view and the argument that country-level differences lead to higher levels of LOF (Eden \& Miller, 2004; Mezias et al., 2002; Xu \& Shenkar, 2002). However, with the increasing shift within institutional analysis to considering firm agency, institutional complexity and institutional entrepreneurship (Kostova et al., 2008; Kostova et al., 2009), research also claimed that the larger the differences between the home-host country institution (institutional asymmetry), the higher the likelihood that AOFs - such as the advantages offered by the home environment will benefit the MNE subsidiary (Edman, 2016b; Insch \& Miller, 2005; Mallon \& Fainshmidt, 2017).

Recently, studies using the identity-based view have attempted to reconcile the difference in degree and difference in kind characteristics of foreignness. Edman (2016b) delineates four distinct difference in degree attributes of foreignness of MNE subsidiaries: individual-level cognition, internal structures and routines, network position and image. Subsidiaries may accentuate or attenuate the degree of foreignness. Subsidiaries are associated with distinct mindsets, routines and structures shaped by the home country and reinforced by the parent firm (Rosenzweig \& Singh, 1991). Because the home and host country are often significantly different in terms of culture, formal institutions and market structures, there is a need for foreign companies to maintain consistency with the parent firm and thus the internal mindset and practices of foreign subsidiaries may not fit with the host country (Kostova \& Zaheer, 1999). Internal attributes represent "differences in degree" rather than "differences in kind" because subsidiaries are not necessarily synonymous with the parent firm (Edman, 
2016b). MNE subsidiaries often implement practices that reflect the pressures from host country institutions, the autonomy the subsidiaries have in the host country and the requirements of the parent network (Kostova \& Roth, 2002; Kostova \& Zaheer, 1999; Yildiz \& Fey, 2012).

The decision to actively embed in a network or maintain a peripheral position is used to manage the degree of foreignness (Edman, 2016a; Luo, Shenkar \& Nyaw, 2002). Subsidiary managers may shape employee assumptions, interpretative frames and mental models acting as "sense-givers" reinforcing a distinct foreign or local identity (Edman, 2016b) and employees may possess both the local and foreign company mindset, acting as "foreign locals" (Newenham-Kahindi \& Stevens, 2017), which may be interpreted as another paradox deserving further analysis. Continuing this line of reasoning, subsidiaries are likely to differ in degree compared to other foreign and local companies, but also compared to other organizational units in their parent-company network, in terms of their foreignness attributes (Edman, 2016b).

Previous studies note the difference in kind characteristic of foreignness resulting from the subsidiaries' network position and foreignness image (Zaheer, 1995, 2002). Network position refers to the degree of embeddedness of a company in the host country (Edman, 2016a; Johanson \& Vahlne, 2009). Foreign companies are often positioned at the periphery or in niche network positions with relatively few relational ties with local stakeholders (Eden \& Miller, 2004; Luo et al., 2002; Zaheer, 2002). MNE subsidiaries manage their network position by building relationships (Luo et al., 2002; Yildiz \& Fey, 2012), but must avoid being overly embedded because of internal and external stakeholder demands and expectations (Edman, 2016a; Li et al., 2007; Regnér \& Edman, 2014).

The identity-based view claims network position and image are external attributes that guide the behaviour of foreign subsidiaries (Edman, 2016a). MNE subsidiaries actively manage 
their network position and image, enhancing the perception and stereotypes of local actors by engaging in CSR (Campbell et al., 2012; Husted et al., 2016). However, subsidiaries "do not have the power to construct and shape foreignness in any way they please" (Edman, 2016b, p.681) because they need to meet other expectations and demands (Kostova et al., 2008). Thus, network position and image represent difference in kind characteristics.

It is instructive to compare the view of foreignness in IB with that of other disciplines. The perception of being foreign and the characteristic of foreignness in a person or an organisation varies across academic disciplines and across epistemological and ontological orientations. In addition, the concept of foreignness does not belong to a particular academic discipline and is often used in terms of differences in kind only. In the fields of political science (especially international relations) and international economics, the concept of foreignness is used to distinguish between different actors and units of analysis, for example foreign country, foreign power or foreign company, in relation to a (domestic) reference actor, implying a binary phenomenon (foreign versus non-foreign/domestic). More of a difference in degree approach is used in sociological approaches (including organisation analysis) and social psychology, where foreignness is understood as a concept that relates to the identity and perception of a particular unit of analysis and is socially constructed. The academic field of IB is building on and combining ideas of international economics, organisation sociology/analysis and social psychology, amongst others, which may explain the variation with which the concepts of foreign and foreignness are applied.

Against the background of different perceptions and understandings of foreignness, our review indicates a shift in the use of theoretical approaches to explore and analyse issues related to foreignness. Over the past 25 years, institutional theory has replaced a more atheoretical and descriptive approach to $\mathrm{LOF} / \mathrm{AOF}$ and now dominates the foreignness literature. Institutional 
theorists are also exploring AOF, especially focusing on the role of foreignness in the interplay between institutions, MNE subsidiaries and strategic responses (Mallon \& Fainshmidt, 2017; Regnér \& Edman, 2014). In doing so, studies based on institutional theory have also explored MNEs' scope for engaging in institutional agency. However, recent studies have increasingly used new theoretical lenses, especially behavioural approaches, such as social justification theory (Balabanis \& Diamantopoulos, 2016), positive organization scholarship (Stahl et al., 2016), the identity-based view (Edman, 2016b), attribution theory (Crilly et al., 2016) and cognitive categorization (Obadia, 2013). These new theories have expanded the foreignness literature, exploring and developing the concept of AOF as well as delineating the relationship with LOF. In addition, with the increasing emphasis on co-evolution (Cantwell et al., 2009; Oetzel \& Doh, 2009); firm responses to institutional diversity, plurality and complexity (Jackson \& Deeg, 2019; Kraatz \& Block, 2008); institutional agency by MNEs (Parente et al., 2018; Saka-Helmhout, 2020); and multiculturalism (Vora et al., 2018) in the IB literature, foreignness research should continue to apply new theoretical lenses to explore and explain the usefulness of these concepts.

Applying different theoretical lenses has opened new research avenues for understanding foreignness and related MNE behaviour (Edman, 2016b; Mallon \& Fainshmidt, 2017). Paradox research (Putnam et al., 2016; Schad et al., 2016) may provide a useful approach from which to integrate the tension and apparent contradiction between the liabilities and assets of foreignness in a revised understanding of the phenomenon of foreignness, at both the conceptual and analytical level. The discussions in this review have demonstrated the dialectical development of the literature, with AOF posited as a direct response to LOF, sometimes based on similar theories and theoretical arguments, other times based on alternative theories. Yet, further insights may emerge by going beyond this traditional (Western) 
dialectical thinking in order to fully grasp the paradoxes of foreignness, as already argued by Fang (2012) for culture. Whereas Western thinking has tended to view paradox as exclusive opposites, Chinese thinking views paradox instead as interdependent opposites (Fang, 2012; Chen, 2002). With respect to the conceptualisation of foreignness, we therefore suggest a paradoxical integration as proposed by Yin Yang philosophy (Fang, 2015; Jing \& Van de Ven, 2015; Li, 2016), i.e. "the notion that two opposites ]...[ may be interdependent in nature and together constitute a totality ("integration")" (Chen, 2002, p.179).

Accordingly, one may conceptualise foreignness as associated with paradoxical dimensions and impact characteristics, organized around three tenets of duality (Li, 2008), namely: 'holistic duality', in which the opposing elements of LOF and AOF are required to constitute the holistic and complete phenomenon of foreignness; 'dynamic duality' in which both LOF and AOF transform "into each other in a process of balancing under various conditions" (Fang, 2015, p.26); and 'dialectical duality' which "posits that the holistic and dynamic tenets can stand because two contrary (relatively contradictory) yet interdependent (relatively compatible) elements exist as opposites in unity to mutually affirm (for consistency and equilibrium) and mutually negate (for completeness and punctuated shift). This is related to the dialectical logic of paradox" (Li, 2008, p.416).

This perspective seems to be able to encompass many key insights on foreignness identified in the literature. Similar to the concept of culture, foreignness is "not a situation-free, time-free and context-free construct, but rather is embedded in situation, context and time" (Fang, 2015, p. 35). The contradictory aspects and impacts of foreignness may co-exist as latent possibilities, that may not only be activated by external circumstances such as socio-economic conditions or even conflicts (Witt, 2019b), but also by actors themselves as they strategically accentuate or attenuate aspects of foreignness (Edmans, 2016b). More broadly, a paradox view 
would suggest that foreignness is not a fixed trait, but is continuously negotiated in the interaction between "foreign" and "local".

Beyond supporting the conceptual understanding of foreignness, paradox theory may also be useful with respect to analysis. Perceptions of foreignness may exist at different organisational levels (for example HQ and subsidiary level), and with respect to different organisational units (for example subsidiaries in different countries). Such perceptions may occur and vary across different individuals in and outside the business organisation. This does not only apply to foreignness perceptions as such, but also to the emergence and existence of LOF and AOF. Overall, a paradox perspective promises to increase our understanding of why foreignness is an asset in certain contexts and a liability in others (Taussig, 2017), as well as the interplay between the individual-level and firm-level perception of foreignness (Edman, 2016b). Referring to dynamic and dialectical duality, , paradox theory could also help us gain a better understanding of the relationships between LOF and AOF, for example being complementary or substitutive, and of the potential displacement effect (Denk et al., 2012) i.e. a dynamic effect whereby the act of managing one AOF/LOF may affect another LOF/AOF. Finally, the dynamic perspective inherent in a paradox approach (Fang, 2012) can also inform the study of the dynamic properties of LOF and AOF with respect to the stability or volatility of LOF and AOF characteristics and dimensions.

Based on the above discussion, we make the following recommendations for future work on the conceptualization of foreignness in IB:

1. Further explore the conceptualizations and disciplinary foundations of foreignness concepts employed in IB studies and their relationship to other theories and concepts in IB, that are themselves often inherited and adapted from foundational disciplines. 
2. Use paradox theory to explore the paradoxical nature of foreignness, and the importance of situation, context and time.

3. Further explore the relationship between LOF and AOF by linking to questions of foreignness as difference in kind and difference in degree and considering the reference point for foreignness.

\subsection{Antecedents, impact and dynamics of foreignness, LOF and AOF}

Strategic management research may be less interested in the concept of foreignness as such, but more in the business implications, its impact on corporate performance and on ways of managing aspects related to foreignness to optimise corporate performance. Before discussing the strategy implications of foreignness, this section paves the way for strategy development by elaborating on the antecedents and attributes as well as the impact of foreignness, which is inextricably linked to debates on liabilities and assets of foreignness.

Several instructive conceptualisations and definitions of LOF and AOF exist in the literature. Based on these, studies to date have endeavoured to determine the antecedents and consequences of, and strategies for managing, LOF and AOF. Yet, most previous studies have held LOF or AOF as a priori assumptions and studied them separately, while the underlying concept of foreignness has received less attention.

However, recent studies have increasingly turned to the concept of foreignness itself, delineating the attributes that make foreign firms foreign and the link between LOF and AOF (Edman, 2016a, 2016b; Newenham-Kahindi \& Stevens, 2017). Understanding the attributes and traits of foreignness is crucial for understanding the link between LOF and AOF as well as the dynamics of foreignness effects and the strategic responses of foreign subsidiaries, but also 
the relationship between institutional processes, subsidiary agency and co-evolution with local contexts (Newenham-Kahindi \& Stevens, 2017; Parente et al., 2018).

Recent work highlights the attributes that make a company "foreign" in the host country (Edman, 2016a, 2016b; Newenham-Kahindi \& Stevens, 2017). Studies using institutional theory posited "marginal and fringe social position[s]" and different cognitive constructs as attributes (Edman, 2016a; Newenham-Kahindi \& Stevens, 2017; Régner \& Edman, 2014; Zaheer, 2002), while the identity-based view claims that assumptions, structure and practice, and distinct expectations are defining attributes of foreignness (Edman, 2016b).

Zaheer and Mosakowski (1997) remind us of the dynamics of the phenomenon. Hymer (1960) suggested that the cost of doing business abroad will decline over time. Studies have also argued that firm-specific resources and the firm's capability of learning about the host market can reduce the liabilities over time (Petersen \& Pedersen, 2002). Eden and Miller (2001) asserted that foreign first movers experience increased LOF once new foreign competition enters the market, which is confirmed by Edman (2016a). Mallon and Fainshmidt (2017) note that AOF follows an inverted U-shaped pattern over time because foreignness will not generate benefits immediately, and benefits will decline after peaking as local firms catch up. Newenham-Kahindi and Stevens (2017) report variation in the degree of LOF faced by foreign companies, as some are able to implement strategies that "fit" the environment, while others are not.

One particularly promising path is the paradox perspective (Hargrave \& Van de Ven, 2017). Liabilities and assets of foreignness can be considered opposite but inseparably linked elements connected to the phenomenon of foreignness, which is inherent to varying degrees in any type of international business activity. From the perspective of management, the 
contradiction between liabilities and assets of foreignness is associated with dynamic tensions, which need to be addressed to achieve MNE objectives.

Managing the contradictions associated with the phenomenon of foreignness is complicated by varying actor constellations and the associated variations in the perception of foreignness. Taking an inside-out perspective, foreignness can be an integral element of an organisation's identity, emerging at the corporate or subsidiary level, potentially varying across different levels (e.g., headquarter versus subsidiary), or between subsidiaries within the same or different countries. From an outside-in perspective, external stakeholders, such as government agencies, suppliers or consumers, may attribute foreign characteristics to the MNE and/or its subsidiaries. The external environment represents a source of varying configurations of latent and manifest liabilities and assets across and within hierarchical levels in the organisation, across and within different stakeholder groups, and over time. This corresponds with organisation identity aspects, with potential variation across and within hierarchical levels. Contradictions and associated tensions may now exist (i) in the external environment, for example between different stakeholders; (ii) within the organisation, for example between headquarters and subsidiaries; and (iii) at the organisation-environment nexus, for example in the form of a mismatch of the organisation's identity with stakeholder perceptions in the external environment of the organisation.

Based on the above, we make the following specific recommendations:

1. Explore the attributes of foreignness from a paradox perspective, whereby specific attributes may become more or less salient over time, based on contextual conditions and the subsidiaries' management of attributes. 
2. Further explore the properties and interdependencies and dynamics of sub-dimensions of LOF and AOF, and the variation across organisational levels (vertical dimension) and subsidiaries (horizontal dimension).

\subsection{Methodology and Empirical Context}

Our findings show a shift in foreignness research in favour of the dyadic perspective, i.e. the study of both the origin and destination of FDI. While quantitative studies still dominate the literature, conceptual and qualitative studies are gaining ground. This shows that scholars have responded to the call of Zaheer (2002) and Denk et al. (2012) for theoretical, methodological and contextual pluralism to expand the concept and investigate underlying mechanisms. For example, Newenham-Kahindi and Stevens (2017) used qualitative methods to provide new insights into LOF research by showing that an antecedent of LOF lies at the firm-level with a difference in logics between local stakeholders and MNEs. Therefore, imitating local norms and behaviours would not be feasible, and instead MNEs need to co-create logics via a relational and reciprocal approach. This article is also notable in that it studied African countries, a context that has been little used in the foreignness literature.

Studies such as Newenham-Kahindi and Stevens (2017) highlight the need for diverse empirical contexts and methodology. Our findings show that the studies investigating FDI flows into emerging markets are dominant, but rather than investigating FDI flows into emerging markets such as China, more studies should focus on complex and "unsettled" environments such as Africa, where AOF could play a relatively greater role. Such environments provide opportunities to explore the diverse role of foreignness in foreign firm strategies and their consequences, as well as identifying the boundary conditions of AOF and LOF, and to understand varying expectations towards foreign firms. Furthermore, a qualitative 
methodology helps to explore the underlying social mechanisms involved in foreignness and the consequences of LOF and AOF.

Based on the above, we make the following specific recommendations for the use of methods and contexts in IB research on foreignness.

1. Continue to explore foreignness in different contexts, especially in "unsettled" environments, where aspects such as conflict, stage of development and colonial history may have implications for foreignness.

2. Explore the potential of inspirations from emerging empirical studies in paradox research, e.g., with respect to the measurement of antecedents, concepts and impact of paradoxes related to foreignness (Miron-Spektor et al., 2018; Zhang et al., 2015) at different levels.

\subsection{The emerging issue: Strategies to manage LOF and AOF}

Drawing on the classic tenets of institutional theory (DiMaggio \& Powell, 1983; North, 1990), many studies on LOF have claimed that institutions constrain MNE operations, thus asserting that foreign companies must learn about host country institutions and engage in isomorphic behaviours to gain legitimacy and reduce LOF (Denk et al., 2012). However, studies of foreignness from the institution-based view increasingly postulate that MNE subsidiaries do not necessarily need to be isomorphic (Kostova et al., 2008; Shi \& Hoskisson, 2012). Instead, these studies claim that the variance in host country environment and local stakeholders' distinct expectations of foreignness enable subsidiary agency, purposive actions to shape the host country institutional environment through compromise, avoidance, defiance and manipulation to create and transform institutions (Kostova et al., 2008; Newenham-Kahindi \& Stevens, 2017; Saka-Helmhout, 2020). 
Studies also provide evidence of foreign companies influencing and changing local institutions, which in turn improves performance (Ghauri et al., 2016; Parente et al., 2018). Foreign companies do not necessarily have to adapt to local norms and imitate locals but can deviate (Shi \& Hoskisson, 2012) and/or innovate (Edman, 2016a) and co-evolve (NewenhamKahindi \& Stevens, 2017; Parente et al., 2018) within local institutions to manage foreignness effects. Despite evidence of subsidiary agency and plurality in strategic responses to managing foreignness, our understanding of why and how subsidiaries pursue a strategy or a mix of strategies is still rudimentary. Denk et al. (2012) state that using one type of strategy would mitigate or aggravate another consequence of LOF and thus call for more scholarly attention to the optimal mix of strategies to manage the displacement effect of LOF. However, so far research has tended to explore specific strategies in isolation. For instance, Edman (2016b) considers how the management of specific attributes of foreignness can affect AOF and LOF, but there could also be spill-over effects between strategies to manage different attributes.

Hence, our final set of recommendations related to researching the management of foreignness include:

1. Further explore the role of foreignness in the interplay between institutions, MNE agency and strategic responses (Jackson \& Deeg, 2019).

2. Further explore the dynamic perspective in strategic responses and strategic diversity, including the potential for management of specific foreignness attributes to interact with the management of other attributes.

3. Use paradox theories to explore the paradoxical nature of foreignness, and the importance of situation, context and time. 


\section{Conclusion: The Future of Foreignness as a Concept within IB}

The phenomenon of foreignness has important links with IB research in general, and more specifically with MNEs' institutional-oriented strategies (Regnér \& Edman, 2014). Denk et al. (2012, p.332) speculated that the concept of LOF might be about to be superseded by other IB concepts from institutional theory, and that "further scrutinizing of the topicality and usefulness of the traditional LoFs concept seems necessary". This is indicated by contributions such as Johanson and Vahlne (2009) taking a network perspective and arguing that the focus should be shifted from "liability of foreignness" to "liability of outsidership".

However, recent research reviewed in this article indicates that, by further elaborating on and refining the conceptualisation of foreignness and building on new theories such as identity theory, the notion of foreignness is likely to continue to play a fundamental role in IB research. This is due not least to the increasing acceptance and integration of new insights and aspects, such as the contrasting view of foreignness as advantage or asset, which is extending and enriching the conceptual and analytical toolbox. For instance, in some cases outsidership caused by foreignness may be an advantage, allowing foreign firms to shield themselves from challenging local norms. However, this aspect does not seem to be fully captured by, for instance, simply inverting the "liability of outsidership" to "asset of outsidership".

Against the background of the complexities involved in international business activities, the paradox perspective on management contradictions provides a means with which to consider, analyse, connect, and integrate the opposite and potentially contradictory but inseparably linked aspects of liabilities and assets of foreignness inside and outside the MNE, and thus offers the opportunity to develop an integrated analytical framework. From the perspective of management, the dichotomy between liabilities and assets of foreignness is associated with dynamic tensions and paradoxes, which need to be addressed to achieve MNE 
objectives. Our review and integration of previous work on antecedents and consequences (cf. tables 4 and 5 above) provides elements of an integrated analytical framework that helps to describe, understand, and analyse various international business-related aspects of foreignness. Foreignness has current and increasing relevance to the changing international business environment, as highlighted by recent trends in many countries to resist globalization (Cuervo-Cazurra et al., 2017; Meyer, 2017; Witt, 2019a,b), the increasing importance and spread of populism (Devinney \& Hartwell, 2020), the re-emergence of (economic) nationalism (Ghauri et al., 2021; Lubinski \& Wadhwani, 2019) and the associated perception and reassessment of foreignness. In this situation an understanding of the meaning(s) of foreignness, its benefits and costs, and strategies for managing foreignness may be of even greater importance. Scholars have already explored some of these issues in the context of deglobalisation. For instance, Witt (2019b) considers how increased animosity towards Chinese firms may lead them to attempt to increase legitimacy in host countries not only by corporate social responsibility and related stakeholder-oriented activities, but also by adjusting ownership structures and ownership shares to mitigate the perceived threat from their activities.

Beyond the elaboration of conceptual and analytical aspects, this review emphasises and expands on the relevance of managing foreignness for international business strategy research and practice. The traditional view is that foreign companies must learn about host country institutions and engage in isomorphic behaviours in order to gain legitimacy and minimize LOF. In line with and as a response to calls to further explore the role of foreignness in the interplay between institutions, MNE agency and strategic responses (Jackson \& Deeg, 2019), this review argues that variation in host country environments and local stakeholders' distinct perceptions and expectations towards foreignness enables subsidiary agency, in terms of purposive actions to manage foreignness aspects and further the MNE's goals and objectives. 
As a consequence, AOF and LOF aspects of foreignness deserve an equally central place in an integrated analytical framework of foreignness in international business strategy.

\section{References}

Acheampong, G., \& Dana, L.-P. (2017). Liability of Foreignness in Fast-Expanding Markets: Evidence from Ghana. Thunderbird International Business Review, Vol. 59 No.1, pp. 51-61

Asmussen, C. G. (2009). Local, regional, or global? Quantifying MNE geographic scope. Journal of International Business Studies. Journal of International Business Studies, Vol. 40 No. 7, pp.1192-1205

Balabanis, G., \& Diamantopoulos, A. (2016). Consumer Xenocentrism as Determinant of Foreign Product Preference: A System Justification Perspective. Journal of International Marketing, Vol. 24 No. 3, pp. 58-77

Beech, N., Burns, H., de Caestecker, L., MacIntosh, R., and MacLean, D. (2016). Paradox as invitation to act in problematic change situations. Human Relations, Vol. 57 No. 10, pp. 1313-1332.

Bell, R. G., Filatotchev, I., \& Rasheed, A. A. (2011). The liability of foreignness in capital markets: Sources and remedies. Journal of International Business Studies, Vol. 43 No. 2, pp. 107-122

Boehe, D. M. (2011). Exploiting the liability of foreignness: Why do service firms exploit foreign affiliate networks at home? Journal of International Management, Vol. 17 No. 1 , pp. 15-29

Brannen, M. Y. (2004). When Mickey loses face: Recontextualization, semantic fit, and the semiotics of foreignness. Academy of Management Review, Vol 29 No. 4, pp. 593-616

Bucheli, M., \& Salvaj, E. (2018). Political connections, the liability of foreignness, and legitimacy: A business historical analysis of multinationals' strategies in Chile. Global Strategy Journal, Vol. 8 No. 3, pp. 399-420

Buckley, P. J., and Lessard, D. R. (2005). Regaining the edge for international business research. Journal of International Business Studies, Vol. 36 No. 6, pp. 595-599

Buckley, P. J., Enderwick, P., and Cross, A. (Eds.). (2018). International business. Oxford University Press

Calhoun, M. A. (2002). Unpacking liability of foreignness: identifying culturally driven external and internal sources of liability for the foreign subsidiary. Journal of International Management, Vol. 8 No. 3, pp. 301-321

Campbell, J. T., Eden, L., \& Miller, S. R. (2012). Multinationals and corporate social responsibility in host countries: Does distance matter? Journal of International Business Studies, Vol 43 No. 1, pp. 84-106

Cantwell, J., Dunning, J. H., \& Lundan, S. M. (2009). An evolutionary approach to understanding international business activity: The co-evolution of MNEs and the institutional environment. Journal of International Business Studies, Vol 41 No. 4, pp. $567-586$

Chen, M.-J. (2002). Transcending Paradox: The Chinese “Middle Way” Perspective*. AsiaPacific Journal of Management, Vol. 19, pp. 179-199 
Crilly, D., Ni, N., \& Jiang, Y. (2016). Do-no-harm versus do-good social responsibility: Attributional thinking and the liability of foreignness. Strategic Management Journal, Vol. 37 No. 7, pp. 1316-1329

Cuervo-Cazurra, A., Maloney, M. M., \& Manrakhan, S. (2007). Causes of the difficulties in internationalization. Journal of International Business Studies, Vol. 38 No. 5, pp. 709-725

Cuervo-Cazurra, A., Mudambi, R., \& Pedersen, T. (2017). Globalization: Rising skepticism. Global Strategy Journal, Vol. 7 No. 2, pp. 155-158

Denk, N., Kaufmann, L., \& Roesch, J. F. (2012). Liabilities of Foreignness Revisited: A Review of Contemporary Studies and Recommendations for Future Research. Journal of International Management, Vol. 18 No. 4, pp. 322-334

Devinney, T. M., and Hartwell, C. A. (2020). Varieties of populism. Global Strategy Journal, Vol. 10 No. 1, pp. 32-66

DiMaggio, P. J., \& Powell, W. W. (1983). The iron cage revisited: Institutional isomorphism and collective rationality in organizational fields. American Sociological Review, Vol. 48 No. 2, pp. 147-160

Eden, L., \& Miller, S. (2001). Opening the black box: The multinational enterprise and the costs of doing business abroad. Best Paper Proceedings, Academy of Management, pp. $1-16$

Eden, L., \& Miller, S. R. (2004). Distance Matters: Liability of Foreignness, Institutional Distance and Ownership Strategy. Advances in International Management, Vol. 16, pp. 187-221

Eden, L., \& Molot, M. (2002). Insiders, outsiders and host country bargains. Journal of International Management, Vol. 8 No. 4, pp. 359-388

Eden, L., and Nielsen, B. B. (2020). Research methods in international business: The challenge of complexity. Journal of International Business Studies, Vol. 51, pp. 16091620

Edman, J. (2016a). Cultivating Foreignness: How Organizations Maintain and Leverage Minority Identities. Journal of Management Studies, Vol. 53 No. 1, pp. 55-88

Edman, J. (2016b). Reconciling the advantages and liabilities of foreignness: Towards an identity-based framework. Journal of International Business Studies, Vol. 47 No. 6, pp. 674-694

Elango, B. (2009). Minimizing effects of 'liability of foreignness': Response strategies of foreign firms in the United States. Journal of World Business, Vol. 44 No.1, pp. 51-62

Fang, T. (2015). Yin Yang: A New Perspective on Culture. Management and Organization Review, Vol. 8 No. 1, pp. 25-50

Forsgren, M. (2017). Theories of the multinational firm: A multidimensional creature in the global economy (3rd ed.). Cheltenham: Edward Elgar

Garg, M., \& Delios, A. (2007). Survival of the foreign subsidiaries of TMNCs: The influence of business group affiliation. Journal of International Management, Vol. 13 No. 3, pp. 278-295

Getachew, Y. S., \& Beamish, P. W. (2017). Foreign Subsidiary Exit from Africa: The Effects of Investment Purpose Diversity and Orientation. Global Strategy Journal, Vol. 7 No. 1, pp. 58-82

Ghauri, P. (2004). Designing and conducting case studies in international business research. In Marschan-Piekkari, R., \& Welch, C. (eds.). Handbook of qualitative research methods for international business. Cheltenham: Edgar Elgar, pp. 109-124 
Ghauri, P., Strange, R., and Cooke, F. L. (2021). Research on international business: The new realities. International Business Review, Vol. 30 No. 2, pp. 1-11

Ghauri, P., Wang, F., Elg, U., \& Rosendo-Ríos, V. (2016). Market driving strategies: Beyond localization. Journal of Business Research, Vol. 69 No. 12, pp. 5682-5693

Goodall, K., \& Roberts, J. (2003). Only connect: teamwork in the multinational. Journal of World Business, Vol. 38 No. 2, pp. 150-164

Greenwood, R., Raynard, M., Kodeih, F., Micelotta, E. R., and Lounsbury, M. (2011). Institutional Complexity and Organizational Responses. The Academy of Management Annals, Vol. 5 No. 1, pp. 317-371

Gaur, A. S., Kumar, V., \& Sarathy, R. (2011). Liability of foreignness and internationalization of emerging market firms. Advances in International Management, Vol. 24, pp. 211-233

Hargrave, T. J., \& Van de Ven, A. H. (2017). Integrating dialectical and paradox perspectives on managing contradictions in organizations. Organization Studies, Vol. 38 No. 3-4, pp. 319-339

Hennart, J. F. (1982). A theory of multinational enterprise. Ann Arbor: University of Michigan Press

Hennart, J. F., Roehl, T., \& Zeng, M. (2002). Do exits proxy a liability of foreignness?: The case of Japanese exits from the US. Journal of International Management, Vol. 8 No. 3, pp. 241-264

Hoon, C., \& Baluch, A. M. (2020). The role of dialectical interrogation in review studies: Theorizing from what we see rather than what we have already seen. Journal of Management Studies, Vol. 57 No. 6, pp. 1246-1271

Husted, B. W., Montiel, I., \& Christmann, P. (2016). Effects of local legitimacy on certification decisions to global and national CSR standards by multinational subsidiaries and domestic firms. Journal of International Business Studies, Vol. 47 No. 3, pp. 382-397

Hymer, S. (1960). On multinational corporations and foreign direct investment. The theory of transnational corporations. London: Routledge for the United Nations

Insch, G. S., \& Miller, S. R. (2005). Perception of foreignness: Benefit or liability? Journal of Managerial Issues, pp. 423-438

Jackson, G., \& Deeg, R. (2019). Comparing capitalisms and taking institutional context seriously. Journal of International Business Studies, Vol. 50 No. 1, pp. 4-19

Johanson, J., \& Vahlne, J.-E. (1977). The internationalization process of the firm-a model of knowledge development and increasing foreign market commitments. Journal of International Business Studies, Vol. 8 No. 1, pp. 23-32

Johanson, J., \& Vahlne, J.-E. (2009). The Uppsala internationalization process model revisited: From liability of foreignness to liability of outsidership. Journal of International Business Studies, Vol. 40 No. 9, pp. 1411-1431

Jing, R., and Van de Ven, A. H. (2015). A Yin-Yang Model of Organizational Change: The Case of Chengdu Bus Group. Management and Organization Review, Vol. 10 No. 1, pp. 29-54

Kline, W. A., \& Brown, R. S. (2019). Overcoming the Liability of Foreignness through Lobbying: an Examination of Franchise Systems. Journal of International Management, Vol. 25 No. 2, pp. 1-1 
Kolk, A., \& Rivera-Santos, M. (2018). The State of Research on Africa in Business and Management: Insights From a Systematic Review of Key International Journals. Business and Society, 57(3), 415-436

Kolk, A., Lindeque, J., \& van den Buuse, D. (2014). Regionalization Strategies of European Union Electric Utilities. British Journal of Management, Vol. 25, S77-S99

Kostova, T., \& Roth, K. (2002). Adoption of an organizational practice by subsidiaries of multinational corporations: Institutional and relational effects. Academy of Management Journal, Vol. 45 No. 1, pp. 215-233

Kostova, T., \& Zaheer, S. (1999). Organizational legitimacy under conditions of complexity: The case of the multinational enterprise. Academy of Management review, Vol. 24 No. 1, pp. 64-81

Kostova, T., Roth, K., \& Dacin, M. (2008). Institutional theory in the study of multinational corporations: A critique and new directions. Academy of Management Review, Vol. 33 No. 4, pp. 994-1006

Kostova, T., Roth, K., \& Dacin, M. T. (2009). Theorizing on MNCs: A promise for institutional theory. Academy of Management review, Vol. 34 No. 1, pp. 171-173

Kraatz, M. S., \& Block, E. S. (2008). Organizational implications of institutional pluralism. In: Greenwood, R., Oliver, C., Sahlin, \& Suddaby, R. (eds) The Sage handbook of organizational institutionalism, Sage: London, pp. 243-275

Kronborg, D., \& Thomsen, S. (2009). Foreign ownership and long-term survival. Strategic Management Journal, Vol. 30 No. 2, pp. 207-219

Lewis, M. W. (2000). Exploring Paradox: Toward a More Comprehensive Guide. Academy of Management Review, Vol. 25, No. 4, pp. 760-776

Li, J., Yang, J. Y., \& Yue, D. R. (2007). Identity, community, and audience: How wholly owned foreign subsidiaries gain legitimacy in China. Academy of Management Journal, Vol. 50 No. 1, pp. 175-190

Li, P. P. (2008). Toward a Geocentric Framework of Trust: An Application to Organizational Trust. Management and Organization Review, Vol. 4 No. 3, pp. 413-439

Li, P. P. (2016). Global implications of the indigenous epistemological system from the east How to apply Yin-Yang balancing to paradox management. Cross Cultural \& Strategic Management, Vol. 23 No. 1, pp. 42-77

Li, Poppo, L., \& Zhou, K. Z. (2008). Do managerial ties in China always produce value? Competition, uncertainty, and domestic vs. foreign firms. Strategic Management Journal, Vol. 29 No. 4, pp. 383-400

Lubinski, C., and Wadhwani, R. D. (2019). Geopolitical jockeying: Economic nationalism and multinational strategy in historical perspective. Strategic Management Journal, Vol. 41 No. 3, pp. 400-421

Luo, Y., \& Mezias, J. (2002). Liabilities of foreignness: Concepts, constructs, and consequences. Journal of International Management, Vol. 8 No. 3, pp. 217-221

Luo, Y., Shenkar, O., \& Nyaw, M. K. (2002). Mitigating liabilities of foreignness: Defensive versus offensive approaches. Journal of International Management. Journal of International Management, Vol. 8 No.3, pp. 283-300

Luo, Y., Zhang, H., \& Bu, J. (2019). Developed country MNEs investing in developing economies: Progress and prospect. Journal of International Business Studies, Vol. 50 No. 4, pp. 633-667 
Lüscher, L. S., and Lewis, M. W. (2008). Organizational change and managerial sensemaking_Working through paradox. Academy of Management Journal, Vol. 51 No. 2, pp. 221-240

Mallon, M. R., \& Fainshmidt, S. (2017). Assets of Foreignness: A Theoretical Integration and Agenda for Future Research. Journal of International Management, Vol. 23 No. 1, pp. $43-55$

Maruyama, M., \& Wu, L. (2015). Overcoming the Liability of Foreignness in International Retailing: A Consumer Perspective. Journal of International Management, Vol. 21 No. 3, pp. 200-210

Meyer, K. E. (2017). International business in an era of anti-globalization. Multinational Business Review, Vol. 25 No. 2, pp. 78-90

Mezias, J. M. (2002a). How to identify liabilities of foreignness and assess their effects on multinational corporations. . Journal of International Management, Vol. 8 No. 3, pp. $265-282$

Mezias, J. M. (2002b). Identifying liabilities of foreignness and strategies to minimize their effects: the case of labor lawsuit judgments in the United States. Strategic Management Journal, Vol. 23 No. 3, pp. 229-244

Mezias, J., \& Mezias, S. (2010). Country level corruption as a liability of foreignness: effects on staffing, incentives, and activities. Advances in International Management, Vol. 23, pp. 267-291

Mezias, S. J., Chen, Y. R., Murphy, P., Biaggio, A., Chuawanlee, W., Hui, H., . . Starr, S. (2002). National cultural distance as liability of foreignness: the issue of level of analysis. Journal of International Management, Vol. 8 No. 3, pp. 407-421

Miller, S. R., \& Eden, L. (2006). Local density and foreign subsidiary performance. Academy of Management Journal, Vol. 49 No. 2, pp. 341-355

Miron-Spektor, E., Ingram, A., Keller, J., Smith, W. K., and Lewis, M. W. (2018). Microfoundations of Organizational Paradox: The Problem Is How We Think about the Problem. Academy of Management Journal, Vol. 61 No. 1, pp. 26-45

Mithani, M. A. (2017). Liability of foreignness, natural disasters, and corporate philanthropy. Journal of International Business Studies, Vol. 48 No. 8, pp. 941-963

Moeller, M., Harvey, M., Griffith, D., \& Richey, G. (2013). The impact of country-of-origin on the acceptance of foreign subsidiaries in host countries: An examination of the 'liability-of-foreignness'. International Business Review, Vol. 22 No. 1, pp. 89-99

Nachum, L. (2003). Liability of foreignness in global competition? Financial service affiliates in the city of London. Strategic Management Journal, Vol. 24 No. 12, pp. 1187-1208

Nachum, L. (2010). When Is Foreignness an Asset or a Liability? Explaining the Performance Differential Between Foreign and Local Firms. Journal of Management, Vol. 36 No. 3, pp. 714-739

Newburry, W., Gardberg, N. A., \& Belkin, L. Y. (2006). Organizational attractiveness is in the eye of the beholder: The interaction of demographic characteristics with foreignness. Journal of International Business Studies, Vol. 37 No. 5, pp. 666-686

Newenham-Kahindi, A., \& Stevens, C. E. (2017). An institutional logics approach to liability of foreignness: The case of mining MNEs in Sub-Saharan Africa. Journal of International Business Studies, Vol. 49 No. 7, pp. 881-901

North, D. C. (1990). Institutions, Institutional Change and Economic Performance. Cambridge: Cambridge University Press. 
Obadia, C. (2013). Foreigness-induced Cognitive Disorientation. Management International Review, Vol. 53 No. 3, pp. 325-360

Oetzel, J., \& Doh, J. P. (2009). MNEs and development: a review and reconceptualization. Journal of World Business, Vol. 44 No. 2, pp. 108-120

Pant, A., and Ramachandran, J. (2017). Navigating identity duality in multinational subsidiaries: A paradox lens on identity claims at Hindustan Unilever 1959-2015. Journal of International Business Studies, Vol. 48 No. 6, pp. 664-692

Parente, R., Rong, K., Geleilate, J.-M. G., \& Misati, E. (2018). Adapting and sustaining operations in weak institutional environments: A business ecosystem assessment of a Chinese MNE in Central Africa. Journal of International Business Studies, Vol. 50 No. 2, pp. 275-291

Petersen, B., \& Pedersen, T. (2002). Coping with liability of foreignness: Different learning engagements of entrant firms. Journal of International Management, Vol. 8 No. 3, pp. 339-350

Pisani, N., Kourula, A., Kolk, A., \& Meijer, R. (2017). How global is international CSR research? Insights and recommendations from a systematic review. Journal of World Business, 52(5), pp. 591-614

Poole, M. S., and Van de Veen, A. H. (1989). Using Paradox to Build Management and Organization Theories. Academy of Management Review, Vol. 14 No. 4, pp. 561-578

Putnam, L. L., Fairhurst, G. T., and Banghart, S. (2016). Contradictions, Dialectics, and Paradoxes in Organizations: A Constitutive Approach $\uparrow$. The Academy of Management Annals, Vol. 10 No. 1, pp. 65-171.

Ramachandran, J., \& Pant, A. (2010). The liabilities of origin: an emerging economy perspective on the costs of doing business abroad. Advances in International Management, Vol. 23, pp. 231-265

Regnér, P., \& Edman, J. (2014). MNE institutional advantage: How subunits shape, transpose and evade host country institutions. Journal of International Business Studies, Vol. 45 No. 3, pp. 275-302

Regnér, P., \& Zander, U. (2014). International Strategy and Knowledge Creation: The Advantage of Foreignness and Liability of Concentration. British Journal of Management, Vol. 25 No. 3, pp. 551-569

Rodgers, W., Alhendi, E., \& Xie, F. (2019). The impact of foreignness on the compliance with cybersecurity controls. Journal of World Business, Vol. 54 No. 6

Rosenzweig, P. M., \& Singh, J. V. (1991). Organizational environments and the multinational enterprise. Academy of Management Review, Vol. 16 No. 2, , pp. 340-361

Saka-Helmhout, A. (2020). Institutional agency by MNEs: A review and future research agenda. Journal of International Management, Vol. 26 No. 2, 100743

Salomon, R., \& Wu, Z. (2012). Institutional distance and local isomorphism strategy. Journal of International Business Studies, Vol. 43 No. 4, pp. 343-367

Schad, J., Lewis, M. W., and Smith, W. K. (2018). Quo vadis, paradox? Centripetal and centrifugal forces in theory development. Strategic Organization, Vol. 17 No. 1, pp. 107-119

Schad, J., Lewis, M. W., Raisch, S., and Smith, W. K. (2016). Paradox Research in Management Science: Looking Back to Move Forward. The Academy of Management Annals, Vol. 10 No. 1, pp. 5-64 
Schmidt, T., \& Sofka, W. (2009). Liability of foreignness as a barrier to knowledge spillovers: Lost in translation? Journal of International Management, Vol. 15 No. 4, pp. 460-474

Sethi, D., \& Guisinger, S. (2002). Liability of foreignness to competitive advantage: How multinational enterprises cope with the international business environment. Journal of International Management, Vol. 8 No. 3, pp. 223-240

Sethi, D., \& Judge, W. (2009). Reappraising liabilities of foreignness within an integrated perspective of the costs and benefits of doing business abroad. International Business Review, Vol. 18 No. 4, pp. 404-416

Shi, W., \& Hoskisson, R. E. (2012). Advantages of Foreignness: Benefits of Creative Institutional Deviance. Advances in International Management, Vol. 25, pp. 99-125

Siegel, J., Pyun, L., \& Cheon, B. (2019). Multinational firms, labor market discrimination, and the capture of outsider's advantage by exploiting the social divide. Administrative Science Quarterly, Vol. 64 No. 2, pp. 370-397

Smith, W. K., and Lewis, M. W. (2011). Toward a theory of paradox: A dynamic equilibrium model of organizing. Academy of Management Review, Vol. 36 No. 2, pp. 381-403

Smith, W. K., and Tracey, P. (2016). Institutional complexity and paradox theory: Complementarities of competing demands. Strategic Organization, Vol. 14 No. 4, pp. 455-466.

Stahl, G. K., Tung, R. L., Kostova, T., \& Zellmer-Bruhn, M. (2016). Widening the lens: Rethinking distance, diversity, and foreignness in international business research through positive organizational scholarship. Journal of International Business Studies, Vol. 47 No. 6, pp. 621-630

Taussig, M. (2017). Foreignness as both a global asset and a local liability: How host country idiosyncrasies and business activities matter. Journal of International Business Studies, Vol. 48 No. 4, pp. 498-522

Tranfield, D., Denyer, D., \& Smart, P. (2003). Towards a methodology for developing evidence-informed management knowledge by means of systematic review. British Journal of Management, Vol. 14 No. 3, pp. 207-222

Un, C. A. (2011). The advantage of foreignness in innovation. Strategic Management Journal, Vol. 32 No. 11, pp. 1232-1242

Un, C. A. (2016). The liability of localness in innovation. Journal of International Business Studies, Vol. 47 No. 1, pp. 44-67

Vora, D., Martin, L., Fitzsimmons, S. R., Pekerti, A. A., Lakshman, C., \& Raheem, S. (2018). Multiculturalism within individuals: A review, critique, and agenda for future research. Journal of International Business Studies, Vol. 50 No. 4, pp. 499-524

Witt, M. A. (2019a), China's challenge: Geopolitics, de-globalization, and the future of Chinese business, Management and Organization Review, Vol. 15 No. 4, pp. 687-704.

Witt, M. A. (2019b), De-globalization: Theories, predictions, and opportunities for international business research, Journal of International Business Studies, Vol. 50 No. 7, pp. 1053-1077.

Wu, Z., \& Salomon, R. (2016). Does imitation reduce the liability of foreignness? Linking distance, isomorphism, and performance. Strategic Management Journal, Vol. 37 No. 12, pp. 2441-2462

Wu, Z., \& Salomon, R. (2017). Deconstructing the liability of foreignness: Regulatory enforcement actions against foreign banks. Journal of International Business Studies, Vol. 48 No. 7 , pp. $837-861$ 
Xu, D., \& Shenkar, O. (2002). Note: Institutional distance and the multinational enterprise. Academy of Management review, Vol. 27 No. 4, pp. 608-618

Yildiz, H. E., \& Fey, C. F. (2012). The liability of foreignness reconsidered: New insights from the alternative research context of transforming economies. International Business Review, Vol. 21 No. 2, pp. 269-280

Yu, J., \& Kim, S. S. (2013). Understanding liability of foreignness in an Asian business context: A study of the Korean asset management industry. Asia Pacific Journal of Management, Vol. 30 No. 4, pp. 1191-1217

Zaheer, S. (1995). Overcoming the liability of foreignness. Academy of Management Journal, Vol. 38 No. 2, pp. 341-363

Zaheer, S. (2002). The liability of foreignness, redux: A commentary Journal of International Management, Vol. 8 No. 3, pp. 351-358

Zaheer, S., \& Mosakowski, E. (1997). The dynamics of the liability of foreignness: A global study of survival in financial services. Strategic Management Journal, Vol. 18 No. 6 , pp. 439-463

Zhang, Y., Waldman, D. A., Han, Y.-L., and Li, X.-B. (2015). Paradoxical Leader Behaviors in People Management: Antecedents and Consequences. Academy of Management Journal, Vol. 58 No. 2, pp. 538-566

Zhou, N., \& Guillen, M. F. (2016). Categorizing the Liability of Foreignness: Ownership, Location, and Internalization-Specific Dimensions. Global Strategy Journal, Vol. 6 No. 4, pp. 309-329 


\section{Appendix}

Figure 1. The process of the systematic literature review

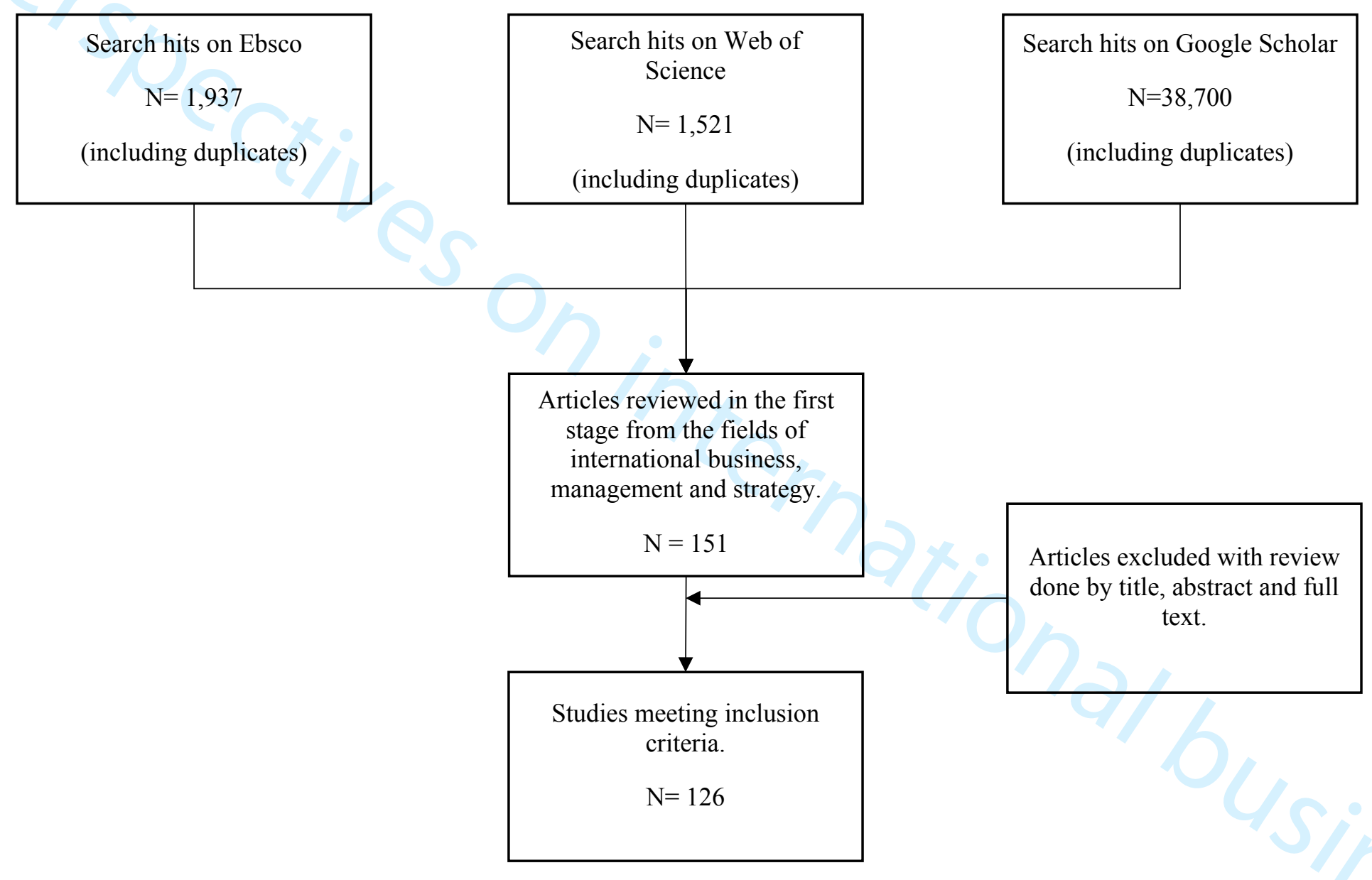


Table 1. List of journals and numbers of articles found related to foreignness in management and international business (1995-2020)

\begin{tabular}{|c|c|c|}
\hline No. & Journal titles in descending order of number of articles & No. of articles found \\
\hline 1. & Journal of International Management & 32 \\
\hline 2. & Journal of International Business Studies & 26 \\
\hline 3. & Journal of World Business & 14 \\
\hline 4. & Strategic Management Journal & 11 \\
\hline 5. & International Business Review & 9 \\
\hline 6. & Advances in International Management & 8 \\
\hline 7. & Academy of Management Journal & 3 \\
\hline 8. & British Journal of Management & 3 \\
\hline 9 & Management International Review & 3 \\
\hline 10. & Global Strategy Journal & 3 \\
\hline 11. & Asia Pacific Journal of Management & 2 \\
\hline 12. & Thunderbird International Business Review & 2 \\
\hline 13. & Academy of Management Review & 1 \\
\hline 14. & Journal of Business Ethics & 1 \\
\hline 15. & Location of International Business & 1 \\
\hline 16 & Journal of Management Studies & 1 \\
\hline 17. & Management Decision & 1 \\
\hline 18. & Strategic Organisation & 1 \\
\hline 19. & Journal of International Marketing & 1 \\
\hline 20 & Administrative Science Quarterly & 1 \\
\hline 21 & Management Business Review & \\
\hline
\end{tabular}


Figure 2. Foreignness studies: Theoretical lenses and research methodology
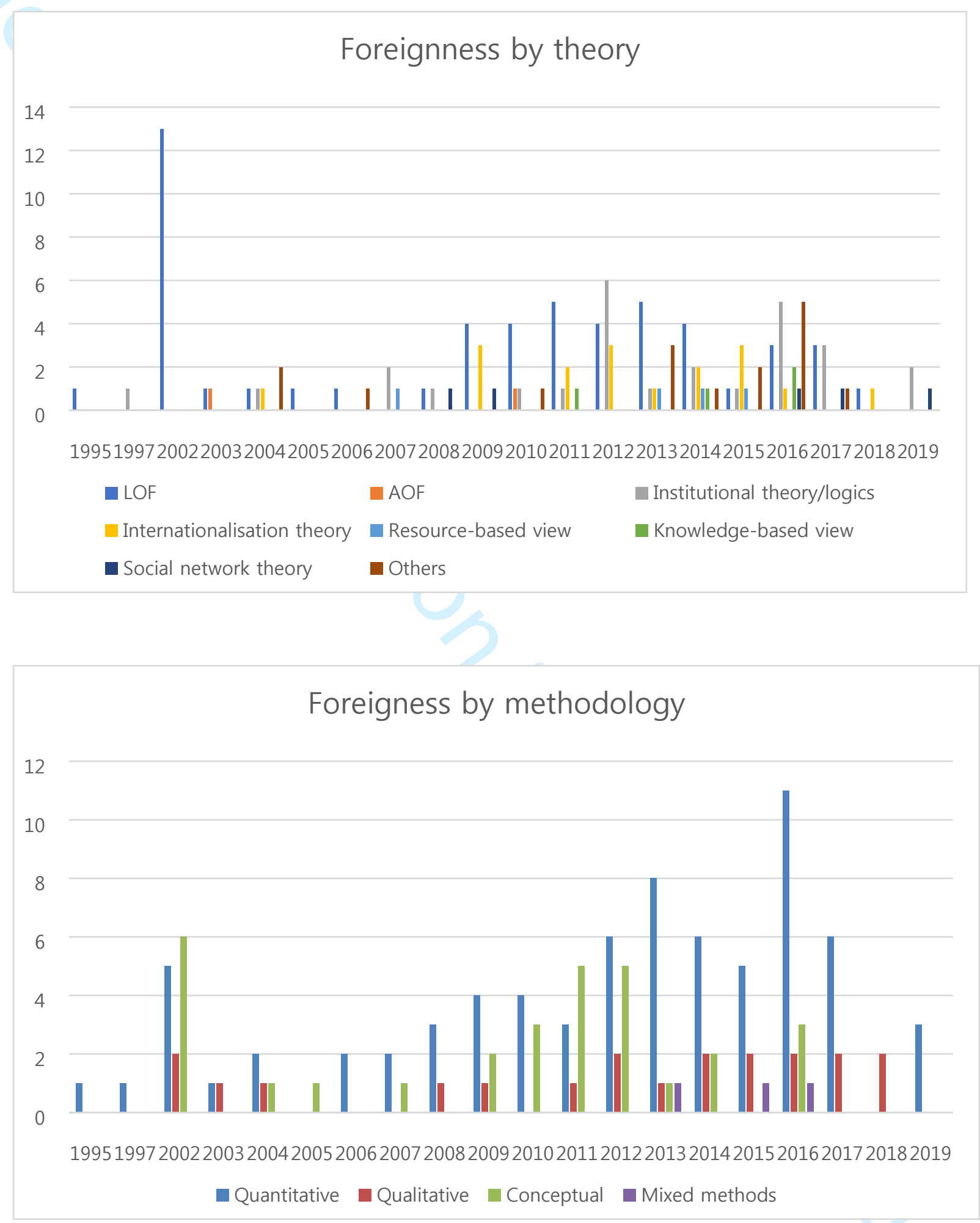
Figure 3. Foreignness studies: Empirical Context
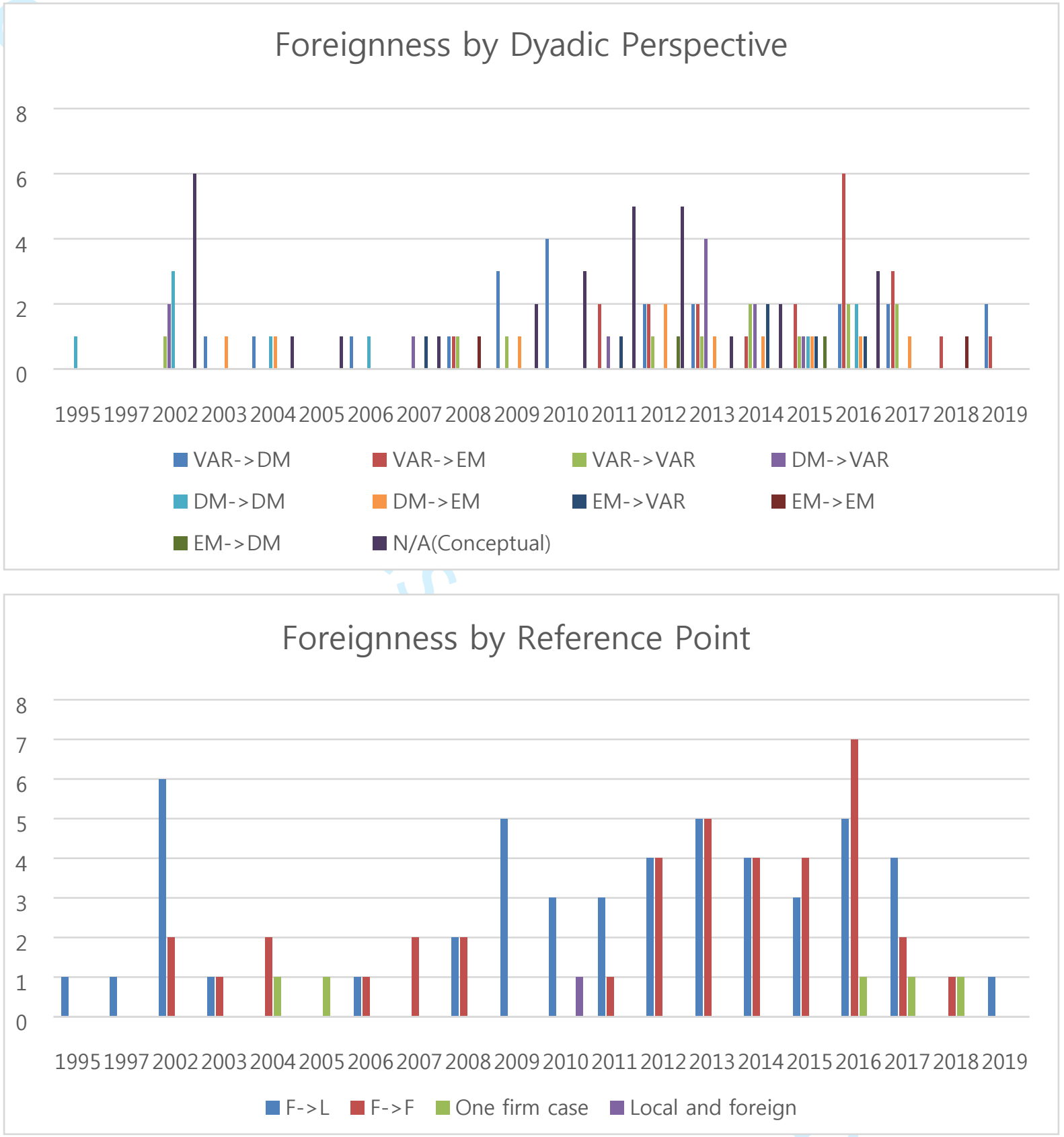

Key: VAR = various, $\mathrm{DM}=$ developed market; $\mathrm{EM}=$ emerging market; $->$ direction of foreign direct investment; $\mathrm{F}->\mathrm{L}=$ Comparison between foreign and local firms; $\mathrm{F}->\mathrm{F}=\mathrm{Comparison}$ between foreign firms 
Table 2. Antecedents of LOF and AOF by theoretical lens*

\begin{tabular}{|c|c|c|}
\hline Theoretical lens & $\mathrm{LOF}$ & $\mathrm{AOF}$ \\
\hline $\begin{array}{l}\text { Internationalization } \\
\text { theory }\end{array}$ & $\begin{array}{l}\text { - Exchange rate risk } \\
\text { - Discrimination } \\
\text { - Lack of familiarity with formal and informal institutions }\end{array}$ & $\begin{array}{l}\text { - Lack of local government and local firm legitimacy } \\
\text { - Host country's need for foreign direct investment } \\
\text { - Lack of dominant incumbent }\end{array}$ \\
\hline Institutional theory & $\begin{array}{l}\text { - Lack of foreign subsidiary legitimacy } \\
\text { - Discrimination } \\
\text { - Lack of familiarity with formal and informal institutions } \\
\text { - External conformity pressures }\end{array}$ & $\begin{array}{l}\text { - Lack of local ties } \\
\text { - Institutional difference between home and host country } \\
\text { - Different cognitive construct } \\
\text { - Complex and heterogeneous host country culture } \\
\text { - Positive perception of foreign firms by local actors }\end{array}$ \\
\hline Social network & $\begin{array}{l}\text { - Lack of social embeddedness and social and political ties } \\
\text { - Lack of trust }\end{array}$ & $\begin{array}{l}\text { - Lack of local ties } \\
\text { - Lack of stakeholder network provides buffer from } \\
\text { conformity pressures }\end{array}$ \\
\hline Resource-based view & $\begin{array}{l}\text { - Costs in transferring firm-specific resources } \\
\text { - Lack of complementary resources required to operate abroad }\end{array}$ & - Firm-specific advantages and home-country advantages \\
\hline $\begin{array}{l}\text { Other theoretical lens } \\
\text { (e.g., agency theory, } \\
\text { identity-based view, } \\
\text { positive scholarship } \\
\text { lens...) }\end{array}$ & $\begin{array}{l}\text { - Home-host country dissimilarity } \\
\text { - Host country homogeneity } \\
\text { - Host country xenophobia } \\
\text { - Distinct cognitive constructs } \\
\text { - Different structures and practices } \\
\text { - Different images and expectations }\end{array}$ & $\begin{array}{l}\text { - Home-host country dissimilarity } \\
\text { - Host country homogeneity } \\
\text { - Host country xenophilia } \\
\text { - Different cognitive constructs } \\
\text { - Different structures and practices } \\
\text { - Different images and expectations }\end{array}$ \\
\hline
\end{tabular}

*From the perspective of the MNE and/or its foreign subsidiary in the host country 
Table 3. Consequences of LOF and AOF by theoretical lens*

\begin{tabular}{|c|c|c|}
\hline Theoretical lens & $\mathrm{LOF}$ & $\mathrm{AOF}$ \\
\hline Internationalization theory & $\begin{array}{l}\text { - Lower performance (ROA, ROS, sales growth) } \\
\text { - Lower survival rate and higher exit rate }\end{array}$ & $\begin{array}{l}\text { - Higher performance (ROA, ROS, sales growth) } \\
\text { - Higher survival rate }\end{array}$ \\
\hline Social network & $\begin{array}{l}\text { - Relational and governance costs } \\
\text { - Barriers to tacit knowledge }\end{array}$ & $\begin{array}{l}\text { - Access to tacit knowledge and information } \\
\text { - Innovation } \\
\text { - Access to unique human capital }\end{array}$ \\
\hline Resource-based view & $\begin{array}{l}\text { - Poorer performance (ROA, ROS, Sales growth) } \\
\text { - Lower survival rate and higher exit rate }\end{array}$ & $\begin{array}{l}\text { - Higher performance (ROA, ROS, sales growth) } \\
\text { - Higher market power } \\
\text { - Access to incentives, subsidies and resources }\end{array}$ \\
\hline
\end{tabular}

*From the perspective of the MNE and/or its foreign subsidiary in the host country 
Table 4. Strategies of LOF and AOF by theoretical lens*

\begin{tabular}{|c|c|c|}
\hline Theoretical lens & LOF & $\mathrm{AOF}$ \\
\hline Internationalization theory & $\begin{array}{l}\text { - Overcoming LOF with firm-specific advantages } \\
\text { - Internalization }\end{array}$ & $\begin{array}{l}\text { - Leveraging internalization advantages } \\
\text { - Leveraging bargaining power with the host country } \\
\text { government } \\
\text { - Leveraging subsidies/incentives }\end{array}$ \\
\hline Institutional theory & $\begin{array}{l}\text { - Imitation or isomorphism } \\
\text { - Transfer of firm-specific advantages } \\
\text { - Nonmarket strategy (e.g. corporate political activity, } \\
\text { lobbying...) } \\
\text { - Circumvention } \\
\text { - Creating new logics }\end{array}$ & $\begin{array}{l}\text { - Exploiting marginal and fringe network position } \\
\text { - Creating new logics with local stakeholders } \\
\text { - Encourage diversity and leverage reflexivity }\end{array}$ \\
\hline Social network & $\begin{array}{l}\text { - Building local ties and becoming embedded in the local } \\
\text { network }\end{array}$ & $\begin{array}{l}\text { - Exploiting niche market } \\
\text { - Less embeddedness in the local network }\end{array}$ \\
\hline Resource-based view & $\begin{array}{l}\text { - Build complementary resources internally } \\
\text { - Develop skills at reading international business environment } \\
\text { - Engage in organization learning processes }\end{array}$ & $\begin{array}{l}\text { - Possessing capabilities to leverage institutional } \\
\text { asymmetries or differences }\end{array}$ \\
\hline $\begin{array}{l}\text { Other theoretical lens (e.g. } \\
\text { agency theory, identity- } \\
\text { based view, positive } \\
\text { scholarship lens...) }\end{array}$ & $\begin{array}{l}\text { - Downplaying foreignness by adapting to local mindset, } \\
\text { imitating local firms' structures and practices, increasing } \\
\text { embeddedness and emphasizing local imagery } \\
\text { - Engaging in proactive CSR activities and creating positive } \\
\text { externalities }\end{array}$ & $\begin{array}{l}\text { - Emphasizing foreignness by leveraging diversity and } \\
\text { foreign mindset, maintaining distinct structure, } \\
\text { lessening embeddedness and emphasizing foreign } \\
\text { imagery }\end{array}$ \\
\hline
\end{tabular}

*From the perspective of the MNE and/or its foreign subsidiary in the host country 


\section{List of References included in the Systematic Review}

Acheampong, G., \& Dana, L. P. 2017. Liability of Foreignness in Fast-Expanding Markets: Evidence from Ghana. Thunderbird International Business Review, 59(1): 51-61.

Almodóvar, P., \& Rugman, A. M. 2014. The M curve and the performance of Spanish international new ventures. British Journal of Management, 25(S1): S6-S23.

Anderson, J., \& Sutherland, D. 2015. Developed economy investment promotion agencies and emerging market foreign direct investment: The case of Chinese FDI in Canada. Journal of World Business, 50(4): 815-825.

Asmussen, C. G. 2009. Local, regional, or global? Quantifying MNE geographic scope. Journal of International Business Studies, 40(7): 1192-1205.

Asmussen, C. G., \& Goerzen, A. 2013. Unpacking Dimensions of Foreignness: Firm-Specific Capabilities and International Dispersion in Regional, Cultural, and Institutional Space. Global Strategy Journal, 3(2): 127-149.

Bae, K. H., Purda, L., Welker, M., \& Zhong, L. 2013. Credit rating initiation and accounting quality for emerging-market firms. Journal of International Business Studies, 44(3): 216-234.

Baik, B., Kang, J. K., Kim, J. M., \& Lee, J. 2013. The liability of foreignness in international equity investments: Evidence from the US stock market. Journal of International Business Studies, 44(4): 391-411.

Balabanis, G., \& Diamantopoulos, A. (2016). Consumer xenocentrism as determinant of foreign product preference: A system justification perspective. Journal of International Marketing, 24(3), 58-77.

Bangara, A., Freeman, S., \& Schroder, W. 2012. Legitimacy and accelerated internationalisation: An Indian perspective. Journal of World Business, 47(4): 623-634.

Barnard, H. 2010. Overcoming the liability of foreignness without strong firm capabilities - the value of market-based resources. Journal of International Management, 16(2): 165-176.

Bell, R. G., Filatotchev, I., \& Rasheed, A. A. 2012. The liability of foreignness in capital markets: Sources and remedies. Journal of International Business Studies, 43(2): 107-122. 
Berger, R., Choi, C. J., \& Kim, J. B. 2011. Responsible leadership for multinational enterprises in bottom of pyramid countries: The knowledge of local managers. Journal of business ethics, 101(4): 553-561.

Beugelsdijk, S. 2011. Liability of foreignness and location-specific advantages: Time, space and relative advantage. In Dynamics of Globalization: Location-Specific Advantages or Liabilities of Foreignness? (pp. 181-210). Emerald Group Publishing Limited.

Bhanji, Z., \& Oxley, J. E. 2013. Overcoming the dual liability of foreignness and privateness in international corporate citizenship partnerships. Journal of International Business Studies, 44(4): 290-311.

Bhaumik, S. K., Driffield, N., \& Zhou, Y. 2016. Country specific advantage, firm specific advantage and multinationality-Sources of competitive advantage in emerging markets: Evidence from the electronics industry in China. International Business Review, 25(1): 165-176.

Boehe, D. M. 2011. Exploiting the liability of foreignness: Why do service firms exploit foreign affiliate networks at home? Journal of International Management, 17(1): 15-29.

Brannen, M. Y. 2004. When Mickey loses face: Recontextualization, semantic fit, and the semiotics of foreignness. Academy of Management Review, 29(4): 593-616.

Bucheli, M., \& Salvaj, E. (2018). Political connections, the liability of foreignness, and legitimacy: A business historical analysis of multinationals' strategies in Chile. Global Strategy Journal, 8(3), 399-420. doi:10.1002/gsj.1195

Bunyaratavej, K., Hahn, E. D., \& Doh, J. P. 2007. International offshoring of services: A parity study. Journal of International Management, 13(1): 7-21.

Calhoun, M. A. 2002. Unpacking liability of foreignness: identifying culturally driven external and internal sources of liability for the foreign subsidiary. Journal of International Management, 8(3): 301-321.

Campbell, J. T., Eden, L., \& Miller, S. R. 2012. Multinationals and corporate social responsibility in host countries: Does distance matter? Journal of International Business Studies, 43(1): 84-106.

Crilly, D., Ni, N., \& Jiang, Y. 2015. Do-no-harm versus do-good social responsibility: Attributional thinking and the liability of foreignness. Strategic management journal. 
Cuervo-Cazurra, A., Maloney, M. M., \& Manrakhan, S. 2007. Causes of the difficulties in internationalization. Journal of International Business Studies, 38(5): 709-725.

Del Bosco, B., \& Misani, N. 2016. The effect of cross-listing on the environmental, social, and governance performance of firms. Journal of World Business, 51(6): 977-990.

Demirbag, M., McGuinness, M., Akin, A., Bayyurt, N., \& Basti, E. 2016. The professional service firm (PSF) in a globalised economy: A study of the efficiency of securities firms in an emerging market. International Business Review, 25(5): 1089-1102.

Denk, N., Kaufmann, L., \& Roesch, J. F. 2012. Liabilities of foreignness revisited: A review of contemporary studies and recommendations for future research. Journal of International Management, 18(4): 322-334.

Eden, L., \& Miller, S. R. 2004. Distance matters: Liability of foreignness, institutional distance and ownership strategy. In "Theories of the Multinational Enterprise: Diversity, Complexity and Relevance" (pp. 187-221). Emerald Group Publishing Limited.

Eden, L., \& Molot, M. A. 2002. Insiders, outsiders and host country bargains. Journal of International Management, 8(4): 359-388.

Edman, J. 2016. Cultivating foreignness: How organizations maintain and leverage minority identities. Journal of Management Studies, 53(1): 55-88.

Edman, J. 2016. Reconciling the advantages and liabilities of foreignness: Towards an identity-based framework. Journal of International Business Studies, 47(6): 674-694.

Elango, B. 2009. Minimizing effects of 'liability of foreignness': Response strategies of foreign firms in the United States. Journal of World Business, 44(1): 51-62.

Elango, B., \& Sambharya, R. B. 2004. The influence of industry structure on the entry mode choice of overseas entrants in manufacturing industries. Journal of International Management, 10(1): 107-124.

Fang, T., Samnani, A. K., Novicevic, M. M., \& Bing, M. N. 2013. Liability-of-foreignness effects on job success of immigrant job seekers. Journal of World Business, 48(1): 98-109.

Filatotchev, I., Bell, R. G., \& Rasheed, A. A. 2016. Globalization of Capital Markets: Implications for Firm Strategies. Journal of International Management, 22(3): 211-221. 
Gallego, Á., \& Casillas, J. C. 2014. Choice of markets for initial export activities: Differences between early and late exporters. International Business Review, 23(5): 1021-1033.

Garg, M., \& Delios, A. 2007. Survival of the foreign subsidiaries of TMNCs: The influence of business group affiliation. Journal of International Management, 13(3): 278-295.

Gaur, A. S., Kumar, V., \& Sarathy, R. 2011. Liability of foreignness and internationalisation of emerging market firms. In Dynamics of Globalization: Location-Specific Advantages or Liabilities of Foreignness? (pp. 211-233). Emerald Group Publishing Limited.

Goerzen, A., Asmussen, C. G., \& Nielsen, B. B. 2014. Global cities and multinational enterprise location strategy. In Location of International Business Activities (pp. 137-180. Palgrave Macmillan UK.

Goodall, K., \& Roberts, J. 2003. Only connect: teamwork in the multinational. Journal of World Business, 38(2): 150-164.

Harvey, M., Novicevic, M. M., Buckley, M. R., \& Fung, H. 2005. Reducing inpatriate managers' 'liability of foreignness' by addressing stigmatization and stereotype threats. Journal of World Business, 40(3): 267-280.

Hennart, J. F., Roehl, T., \& Zeng, M. 2002. Do exits proxy a liability of foreignness?: The case of Japanese exits from the US. Journal of International Management, 8(3): 241-264.

Husted, B. W., Montiel, I., \& Christmann, P. 2016. Effects of local legitimacy on certification decisions to global and national CSR standards by multinational subsidiaries and domestic firms. Journal of International Business Studies, 47(3): 382-397.

Jiang, F., \& Stening, B. W. 2013. Do indigenous firms incur a liability of localness when operating in their home market? The case of China. Journal of World Business, 48(4): 478-489.

Johanson, J., \& Vahlne, J. E. 2009. The Uppsala internationalization process model revisited: From liability of foreignness to liability of outsidership. Journal of international business studies, 40(9): 1411-1431.

Kim, H., \& Jensen, M. 2014. Audience heterogeneity and the effectiveness of market signals: How to overcome liabilities of foreignness in film exports? Academy of Management Journal, 57(5): 1360-1384.

Kline, W. A., \& Brown, R. S. (2019). Overcoming the Liability of Foreignness through Lobbying: an Examination of Franchise Systems. Journal of International Management, 25(2). doi:10.1016/j.intman.2018.11.004 
Klossek, A., Linke, B. M., \& Nippa, M. 2012. Chinese enterprises in Germany: Establishment modes and strategies to mitigate the liability of foreignness. Journal of World Business, 47(1): 35-44.

Kolk, A., Lindeque, J., \& Buuse, D. 2014. Regionalization strategies of European Union electric utilities. British Journal of Management, 25(S1): S77-S99.

Kronborg, D., \& Thomsen, S. 2009. Foreign ownership and long-term survival. Strategic Management Journal, 30(2): $207-219$.

Kudina, A. 2012. Regional strategies, liability of foreignness, and firm performance. Multinational Business Review, 20(4): 331-351.

Kuznetsov, A., \& Kuznetsova, O. 2014. Building professional discourse in emerging markets: Language, context and the challenge of sensemaking. Journal of International Business Studies, 45(5): 583-599.

Lamin, A., \& Livanis, G. 2013. Agglomeration, catch-up and the liability of foreignness in emerging economies. Journal of International Business Studies, 44(6): 579-606.

Laudien, S. M., \& Freiling, J. 2011. Overcoming liabilities of foreignness by modes of structural coordination: Regional headquarters and their role in TNCs. In Dynamics of Globalization: Location-Specific Advantages or Liabilities of Foreignness? (pp. 107-125). Emerald Group Publishing Limited.

Li, J. J., Poppo, L., \& Zhou, K. Z. 2008. Do managerial ties in China always produce value? Competition, uncertainty, and domestic vs. foreign firms. Strategic Management Journal, 29(4): 383-400.

Li, S., Easterby-Smith, M., Lyles, M. A., \& Clark, T. 2016. Tapping the power of local knowledge: A local-global interactive perspective. Journal of World Business, 51(4): 641-653.

Li, W., Bruton, G. D., \& Filatotchev, I. 2016. Mitigating the dual liability of newness and foreignness in capital markets: The role of returnee independent directors. Journal of World Business, 51(5): 787-799.

Lindorfer, R., d'Arcy, A., \& Puck, J. 2016. Location Decisions and the Liability of Foreignness: Spillover Effects Between Factor Market and Capital Market Strategies. Journal of International Management, 22(3): 222-233.

Lu, Q., \& Hwang, P. 2010. The impact of liability of foreignness on international venture capital firms in Singapore. Asia Pacific Journal of Management, 27(1): 81-97. 
Luo, Y., \& Mezias, J. M. 2002. Liabilities of foreignness: Concepts, constructs, and consequences. Journal of International Management, 8(3): 217-221.

Luo, Y., Shenkar, O., \& Nyaw, M. K. 2002. Mitigating liabilities of foreignness: Defensive versus offensive approaches. Journal of International Management, 8(3): 283-300.

Mallon, M. R., \& Fainshmidt, S. 2017. Assets of Foreignness: A Theoretical Integration and Agenda for Future Research. Journal of International Management, 23(1): 43-55.

Maruyama, M., \& Wu, L. 2015. Overcoming the liability of foreignness in international retailing: a consumer perspective. Journal of International Management, 21(3): 200-210.

Mata, J., \& Freitas, E. 2012. Foreignness and exit over the life cycle of firms. Journal of International Business Studies, 43(7): 615-630.

Mezias, J. M., \& Mezias, S. J. 2010. Country level corruption as a liability of foreignness: Effects on staffing, incentives, and activities. In The Past, Present and Future of International Business \& Management (pp. 267-291). Emerald Group Publishing Limited.

Mezias, J. M. 2002. How to identify liabilities of foreignness and assess their effects on multinational corporations. Journal of International Management, 8(3): 265-282.

Mezias, J. M. 2002. Identifying liabilities of foreignness and strategies to minimize their effects: The case of labor lawsuit judgments in the United States. Strategic Management Journal, 23(3): 229-244.

Mezias, S. J., Chen, Y. R., Murphy, P., Biaggio, A., Chuawanlee, W., Hui, H., ... \& Starr, S. 2002. National cultural distance as liability of foreignness: the issue of level of analysis. Journal of International Management, 8(4): 407-421.

Miller, S. R., \& Eden, L. 2006. Local density and foreign subsidiary performance. Academy of Management journal, 49(2): $341-355$.

Miller, S. R., \& Parkhe, A. 2002. Is there a liability of foreignness in global banking? An empirical test of banks' X-efficiency. Strategic Management Journal, 23(1): 55-75.

Miller, S. R., \& Richards, M. 2002. Liability of foreignness and membership in a regional economic group: Analysis of the European Union. Journal of International Management, 8(3): 323-337.

Mithani, M. A. (2017). Liability of foreignness, natural disasters, and corporate philanthropy. Journal of International Business Studies, $48(8), 941-963$ 
Moeller, M., Harvey, M., Griffith, D., \& Richey, G. 2013. The impact of country-of-origin on the acceptance of foreign subsidiaries in host countries: An examination of the 'liability-of-foreignness'. International Business Review, 22(1): 89-99.

Muzychenko, O., \& Liesch, P. W. 2015. International opportunity identification in the internationalisation of the firm. Journal of World Business, 50(4): 704-717.

Nachum, L. 2003. Liability of foreignness in global competition? Financial service affiliates in the city of London. Strategic Management Journal, 24(12): 1187-1208.

Nachum, L. 2010. Foreignness, multinationality and inter-organizational relationships. Strategic Organization, 8(3): $230-254$.

Nachum, L. 2010. When is foreignness an asset or a liability? Explaining the performance differential between foreign and local firms. Journal of Management, 36(3): 714-739.

Newburry, W., Gardberg, N. A., \& Belkin, L. Y. 2006. Organizational attractiveness is in the eye of the beholder: The interaction of demographic characteristics with foreignness. Journal of International Business Studies, 37(5): 666-686.

Newburry, W., Gardberg, N. A., \& Sanchez, J. I. 2014. Employer attractiveness in Latin America: The association among foreignness, internationalization and talent recruitment. Journal of International Management, 20(3): 327-344.

Newenham-Kahindi, A., \& Stevens, C. E. (2017). An institutional logics approach to liability of foreignness: The case of mining MNEs in Sub-Saharan Africa. Journal of International Business Studies, 49(7), 881-901.

Obadia, C. 2013. Foreigness-induced cognitive disorientation. Management International Review, 53(3): 325-360.

Oetzel, J., \& Doh, J. P. 2009. MNEs and development: a review and reconceptualization. Journal of World Business, 44(2): 108-120.

Oh, C. H., Sohl, T., \& Rugman, A. M. 2015. Regional and product diversification and the performance of retail multinationals. Journal of International Management, 21(3): 220-234.

Orr, R. J., \& Scott, W. R. 2008. Institutional exceptions on global projects: a process model. Journal of International Business Studies, 39(4): $562-588$.

Parente, R., Rong, K., Geleilate, J.-M. G., \& Misati, E. (2018). Adapting and sustaining operations in weak institutional environments: A business ecosystem assessment of a Chinese MNE in Central Africa. Journal of International Business Studies, 50(2), $275-291$. 
Perez-Batres, A. P. L. A., Miller, V. V., Pisani, M. J., Henriques, I., \& Renau-Sepulveda, G. A. J. A. 2012. Why do firms engage in national sustainability programs and transparent sustainability reporting? Management international review, 52(1): 107-136. 7 .

Perez-Batres, L. A., \& Eden, L. 2008. Is there a liability of localness? How emerging market firms respond to regulatory punctuations. Journal of International Management, 14(3): 232-251.

Petersen, B., \& Pedersen, T. 2002. Coping with liability of foreignness: Different learning engagements of entrant firms. Journal of International Management, 8(3): 339-350.

Qian, G., Li, L., \& Rugman, A. M. 2013. Liability of country foreignness and liability of regional foreignness: Their effects on geographic diversification and firm performance. Journal of International Business Studies, 44(6): 635-647.

Ramachandran, I., Clark, K., McIver, D., \& Miller, S. R. 2011. Selecting State or Private Joint Venture Partners in Emerging Markets: Impact of Liability of Foreignness and Rule of Law. In Dynamics of Globalization: Location-Specific Advantages or Liabilities of Foreignness? (pp. 153-179). Emerald Group Publishing Limited.

Ramachandran, J., \& Pant, A. 2010. The liabilities of origin: An emerging economy perspective on the costs of doing business abroad. In The past, present and future of international business \& management (pp. 231-265). Emerald Group Publishing Limited.

Rangan, S., \& Drummond, A. 2004. Explaining outcomes in competition among foreign multinationals in a focal host market. Strategic Management Journal, 25(3): 285-293.

Reade, C., \& Lee, H. J. 2012. Organizational commitment in time of war: Assessing the impact and attenuation of employee sensitivity to ethnopolitical conflict. Journal of International Management, 18(1): 85-101.

Regnér, P., \& Edman, J. 2014. MNE institutional advantage: How subunits shape, transpose and evade host country institutions. Journal of International Business Studies, 45(3): 275-302.

Regnér, P., \& Zander, U. 2014. International strategy and knowledge creation: The advantage of foreignness and liability of concentration. British Journal of Management, 25(3): 551-569.

Rodgers, W., Alhendi, E., \& Xie, F. (2019). The impact of foreignness on the compliance with cybersecurity controls. Journal of World Business, 54(6). doi:10.1016/j.jwb.2019.101012.

Salomon, R., \& Wu, Z. 2012. Institutional distance and local isomorphism strategy. Journal of International Business Studies, 43(4): 343-367. 
Schmidt, T., \& Sofka, W. 2009. Liability of foreignness as a barrier to knowledge spillovers: Lost in translation? Journal of International Management, 15(4): 460-474.

Sethi, D., \& Guisinger, S. 2002. Liability of foreignness to competitive advantage: How multinational enterprises cope with the international business environment. Journal of International Management, 8(3): 223-240.

Sethi, D., \& Judge, W. 2009. Reappraising liabilities of foreignness within an integrated perspective of the costs and benefits of doing business abroad. International Business Review, 18(4): 404-416. 7.

Sharp, Z. 2010. From unilateral transfer to bilateral transition: Towards an integrated model for language management in the MNE. Journal of International Management, 16(3): 304-313.

Shi, W., \& Hoskisson, R. E. 2012. Advantages of foreignness: Benefits of creative institutional deviance. In Institutional Theory in International Business and Management (pp. 99-125). Emerald Group Publishing Limited.

Siegel, J., Pyun, L., \& Cheon, B. (2019). Multinational firms, labor market discrimination, and the capture of outsider's advantage by exploiting the social divide. Administrative Science Quarterly, 64(2), 370-397.

Slangen, A. H., Beugelsdijk, S., \& Hennart, J. F. 2011. The impact of cultural distance on bilateral arm's length exports. Management International Review, 51(6): 875-896.

Sofka, W., \& Zimmermann, J. 2008. Regional economic stress as moderator of liability of foreignness. Journal of International Management, 14(2): 155-172.

Sojli, E., \& Tham, W. W. 2017. Foreign political connections. Journal of International Business Studies, 48(2): 244-266.

Stahl, G. K., Tung, R. L., Kostova, T., \& Zellmer-Bruhn, M. 2016. Widening the lens: Rethinking distance, diversity, and foreignness in international business research through positive organizational scholarship.

Stevens, C. E., \& Shenkar, O. 2012. The liability of home: Institutional friction and firm disadvantage abroad. In Institutional theory in international business and management (pp. 127-148). Emerald Group Publishing Limited.

Taussig, M. 2017. Foreignness as both a global asset and a local liability: How host country idiosyncrasies and business activities matter. Journal of International Business Studies, 48(4): 498-522. 
Temouri, Y., Driffield, N., \& Bhaumik, S. K. 2016. A strategic perspective of cross-listing by emerging market firms: Evidence from Indonesia, Mexico, Poland and South Africa. Journal of International Management, 22(3): 265-279.

Un, C. A. 2011. The advantage of foreignness in innovation. Strategic Management Journal, 32(11): 1232-1242.

Un, C. A. 2016. The liability of localness in innovation. Journal of International Business Studies, 47(1): 44-67.

Varum, C. A., \& Rocha, V. C. B. 2011. Do foreign and domestic firms behave any different during economic slowdowns? International Business Review, 20(1): 48-59.

Varum, C., Rocha, V. C., \& da Silva, H. V. 2014. Economic slowdowns, hazard rates and foreign ownership. International Business Review, 23(4): 761-773.

Wang, P. 2017. Syndication and Foreignness: Venture Capital Investments in Emerging and Developed Markets. Journal of International Management, 23(1): 1-15.

Wei, T., \& Clegg, J. 2015. Overcoming the liability of foreignness in internationalization in emerging economies: Lessons from acquiring a Chinese firm. Thunderbird International Business Review, 57(2): 103-117.

Wöcke, A., \& Moodley, T. 2015. Corporate political strategy and liability of foreignness: Similarities and differences between local and foreign firms in the South African Health Sector. International Business Review, 24(4): 700-709.

Wu, Z., \& Salomon, R. 2016. Does imitation reduce the liability of foreignness? Linking distance, isomorphism, and performance. Strategic Management Journal.

Wu, Z., \& Salomon, R. (2017). Deconstructing the liability of foreignness: Regulatory enforcement actions against foreign banks. Journal of International Business Studies, 48(7), 837-861.

Yildiz, H. E., \& Fey, C. F. 2012. The liability of foreignness reconsidered: New insights from the alternative research context of transforming economies. International Business Review, 21(2): 269-280.

Yu, J., \& Kim, S. S. 2013. Understanding liability of foreignness in an Asian business context: A study of the Korean asset management industry. Asia Pacific Journal of Management, 30(4): 1191-1217.

Yu, Y., \& Sharma, R. R. 2016. Dancing with the stars: what do foreign firms get from high-status local partners? Management Decision, 54(6): 1294-1319. 
Zaheer, S. 1995. Overcoming the liability of foreignness. Academy of Management journal, 38(2): 341-363.

Zaheer, S. 2002. The liability of foreignness, redux: A commentary. Journal of International Management, 8(3): 351-358.

Zaheer, S., \& Mosakowski, E. 1997. The dynamics of the liability of foreignness: A global study of survival in financial services. Strategic management journal, 439-463.

Zhou, N., \& Guillen, M. F. 2016. Categorizing the Liability of Foreignness: Ownership, Location, and Internalization-Specific Dimensions. Global Strategy Journal, 6(4): 309-329.

Zhou, N., \& Guillén, M. F. 2015. From home country to home base: A dynamic approach to the liability of foreignness. Strategic Management Journal, 36(6): 907-917. 